Article

\title{
Deciphering the Antitussive, Expectorant, and Anti-Inflammatory Potentials of ShashamKyeongok-Go and Their Phytochemical Attributes: In Vivo Appraisal in ICR Mice
}

\author{
Jin-Ryul Hu ${ }^{1}$, Chul-Jong Jung ${ }^{2}{ }^{\circledR}$, Seong-Min Ku ${ }^{2}$, Dae-Hwa Jung ${ }^{3}$, Sae-Kwang Ku ${ }^{1,4}{ }^{\oplus}$, Md. Mohibbullah ${ }^{5}{ }^{\oplus}$, \\ Hae-Jeung Lee ${ }^{6, *(1)}$ and Jae-Suk Choi ${ }^{7, *(1)}$
}

check for updates

Citation: Hu, J.-R.; Jung, C.-J.; Ku, S.-M.; Jung, D.-H.; Ku, S.-K.;

Mohibbullah, M.; Lee, H.-J.; Choi, J.-S. Deciphering the Antitussive,

Expectorant, and Anti-Inflammatory Potentials of ShashamKyeongok-Go and Their Phytochemical Attributes: In Vivo Appraisal in ICR Mice. Appl. Sci. 2021, 11, 1349. https://doi.org/ 10.3390/app11031349

Academic Editor: Carmela Spagnuolo Received: 16 December 2020

Accepted: 28 January 2021

Published: 2 February 202

Publisher's Note: MDPI stays neutra with regard to jurisdictional claims in published maps and institutional affiliations.

Copyright: (c) 2021 by the authors Licensee MDPI, Basel, Switzerland. This article is an open access article distributed under the terms and conditions of the Creative Commons Attribution (CC BY) license (https:// creativecommons.org/licenses/by/ $4.0 /)$
1 Department of Histology and Anatomy, Daegu Haany University, Gyeongsan-si 38610, Gyeongsangbuk-do, Korea; jinlyul@gmail.com (J.-R.H.); gucci200@hanmail.net (S.-K.K.)

2 Okchundang Inc., Ulju-gun 44900, Ulsan, Korea; okchundang300@gmail.com (C.-J.J.); qltkd71@hanmail.net (S.-M.K.)

3 Department of Pharmaceutical Engineering, Daegu Haany University, Gyeongsan 38610, Gyeongsangbuk-do, Korea; jdh8024@hanmail.net

4 The Medical Research Center for Herbal Convergence on Liver Disease, Daegu Haany University, Gyeongsan-si 38610, Gyeongsangbuk-do, Korea

5 Department of Fishing and Post Harvest Technology, Sher-e-Bangla Agricultural University, Dhaka 1207, Bangladesh; mmohib.fpht@sau.edu.bd

6 Department of Food and Nutrition, Gachon University, 1342 Seongnamdaero, Sujeong-gu, Seongnam 13120, Gyeonggi, Korea

7 Department of Food Biotechnology, Silla University, Sasang-gu 46958, Busan, Korea

* Correspondence: skysea@gachon.ac.kr (H.-J.L.); jsc1008@silla.ac.kr (J.-S.C.); Tel.: +82-31-750-5968 (H.-J.L.); +82-51-248-7789 (J.-S.C.)

\begin{abstract}
In this paper, we hypothesized that ShashamKyeongok-go (SKOG) is a mixed preparation of Adenophorae Radix powder (AR) and Kyeongok-go (KOG). SKOG may be served as a novel preventive and/or therapeutic agent for various respiratory diseases. SKOG were orally administered to ICR mice at 400,200 , and $100 \mathrm{mg} / \mathrm{kg}$ once a day for 11 days to examine antitussive, expectorant, and anti-inflammatory effects. The $\mathrm{NH}_{4} \mathrm{OH}$ exposure-induced allergic acute inflammation with coughing responses was dose-dependently and significantly $(p<0.01)$ inhibited by pretreatment with SKOG at doses of 400, 200, and $100 \mathrm{mg} / \mathrm{kg}$. With these concentrations of SKOG, the thickness of intrapulmonary secondary bronchus mucosa and the number of periodic acid Schiff stain-positive mucous-producing cells were significantly $(p<0.05$ or $p<0.01)$ increased, as a result of the increased amount of phenol red secretion. Subsequently, SKOG showed significant $(p<0.01)$ anti-inflammatory activities as characterized by reducing the effects of xylene-induced increases of ear weight, thickness of total ear and ear dermis, and number of infiltrated inflammatory cells in the ear dermis, in a dose-dependent manner. These results supported that SKOG might have potential therapeutic effects to be used as an antitussive, expectorant, and anti-inflammatory agents in the prevention or treatment of chronic bronchitis and asthma.
\end{abstract}

Keywords: shashamkyeongok-go; kyeongok-go; adenophorae radix; antitussive effects; expectorant effects; anti-inflammation

\section{Introduction}

Airways bronchitis and asthma are a chronic inflammatory disease occupied in the respiratory tract and possibly caused by inherited predisposition and long-term effects of environmental irritants such as dust mites, smoke, and various chemical irritants. Bronchoconstriction is one of the most frequent pathological events of having chronic bronchitis and asthma, where the airway tubes become narrower and harder, but which is supposed to be wider and smoother, in reaction to the introduced foreign particles [1]. Therefore, it affects patients with difficulty to breathe properly associated with cough induction. A 
cough is defined as, voluntary or involuntary acts, a forced expulsion behavior to clear the throat, and breathing airways with a concomitant sound. In addition, it has two characteristic types including non-productive as dry and productive as chesty, which are exhaustive and adversely affect the quality of life [2]. It represents global public health problems which are likely to be enormously higher, more than 339 million people currently suffer from asthma [3]. Moreover, compelling evidence suggested that inflammatory processes in airways were implicated in developing the pathogenesis of many respiratory diseases $[4,5]$. Therefore, the present study is undertaken to search for new natural herb-based formulations acting as alternative therapeutics, which are rich in nature, deciphering the synergistic effects in antitussive, expectorant, and anti-inflammatory activities in patients with airways bronchitis and asthma complications.

Adenophora triphylla var. japonica Hara is under the genus of Adenophora (Campanulaceae), and has been documented as an oriental medicinal prescription in Korea, Japan, and China. Pharmacological potentials of $A$. triphylla are characterized by its antitussive, anti-inflammatory [6], and hepatoprotective properties [7,8]. Many of the pharmacological important compounds of dried root parts of $A$. triphylla are reported as triterpenoids, alkaloids, and various essential oil compounds including pyrrolidine and triphyllol [6], piperidine and heptacosane [9], lupenone [10,11], and saponine [12,13]. In addition, precedent research on the dried root parts of $A$. triphylla, alternatively known as Adenophorae Radix, have remarkable effects on in vitro mucus production [14], in vivo hepatoprotective [7], in vitro antitumor [12,13], and in vitro [8,10] and in vivo anti-obesity [8]. Kyeongok-go (KOG) is one of the widely accepted and most popular herbal recipes in oriental medicine of Korea, comprising of Rehmanniae Radix Crudus, Pulvis Hoelen, Ginseng Radix Alba, and honey $[7,15]$. Many experimental evidence showed the path of pharmacological importance of KOG by the researchers on antioxidant [15], anti-inflammatory [16], immunomodulatory [15], anti-fatigue and aerobic-capacity enhancing [16], and growth-promoting [17] potentials.

Therefore, we hypothesized and expected that the appropriate addition of Adenophorae Radix powders (AR) to KOG can potentiate antitussive, expectorant, and anti-inflammatory activities, which may be utilized as a novel tonic agent for preventing varied respiratory diseases. The present study was conducted in three different mouse models, such as $\mathrm{NH} 4 \mathrm{OH}$-induced coughing [18,19], phenol red secretion [18,20], and xylene-induced acute inflammation in the ear [21,22], to perform antitussive, expectorant, and anti-inflammatory assays, respectively. The obtained results from SKOG treatment groups were compared side-by-side with a single dose of AR, KOG and/or standard drugs of theobromine (TB), ambroxol (AM), and dexamethasone (DEXA), respectively [14,23], aiming at examining the synergistic effects of SKOG on the mitigation of chronic bronchitis and asthma.

\section{Materials and Methods}

\subsection{Test Materials}

Yellow-coloured and powdered forms of AR, KOG, and SKOG materials were supplied by Okchundang (Ulsan, Korea). To prepare KOG, briefly, appropriate amounts of individual herbs, namely Ginseng Radix Alba (6000 g), Pulvis Hoelen (12,000 g), Rehmanniae Radix Crudus $(47,000 \mathrm{~g})$, and honey $(39,000 \mathrm{~g})$, were mixed, heated at $60^{\circ} \mathrm{C}$ for $72 \mathrm{~h}$, and cooled at $20^{\circ} \mathrm{C}$; this process was repeated twice. To prepare SKOG, appropriate amounts of individual herbs, namely Ginseng Radix Alba (4500 g), Pulvis Hoelen (9000 g), AR (4500 g), Rehmanniae Radix Crudus (47,000 g), and honey (39,000 g) were mixed, heated in a water bath at $60^{\circ} \mathrm{C}$ for $72 \mathrm{~h}$, and cooled at $20^{\circ} \mathrm{C}$; this process was repeated twice (Table S1). Specimens of AR, KOG, and SKOG were deposited in the herbarium of the Medical Research Center, Daegu Haany University (Gyeongsan, Gyeongbuk, Korea) (code no. AR2016Ku01, KOG2016Ku01, and SKOG2016Ku01, respectively). Unless otherwise stated, all chemicals used in the study were purchased from Sigma-Aldrich LLC (St. Louis, $\mathrm{MO}$, USA) and kept at $4{ }^{\circ} \mathrm{C}$ until use. 


\subsection{Analysis of Specific Ingredients of $A R, K O G$, and SKOG}

2.2.1. Instrument and Reagents

An ultra-performance liquid chromatography (UPLC) system (Waters Corp., Milford, MA, USA) was used, where the photodiode array detector (PDA; Waters Corp.), Waters ACQUITYT SM (Sample Manager) Autosampler, Waters ACQUITYT CH-A Column Oven $\left(20^{\circ} \mathrm{C}\right)$, and $\mathrm{C} 18$ column with a dimension of $1.7 \mu \mathrm{m}, 2.1 \times 100 \mathrm{~mm}$ (ACQUITYTM BEH, Waters Corp.) were adjusted to the system [24]. The UPLC chromatogram was visualized using an Empower Software (Waters Corp.) equipped with the computer system. The sample extractor was an 8210R-DHT ultrasonicator (Branson Ultrasonics, Danbury, CT, USA). The HPLC grade extraction solvents were methanol (MeOH; Junsei Chemical Co., Ltd., Tokyo, Japan) and acetonitrile (BAKER, Center Valley, PA, USA). In case of the PDA analysis, the detection wavelength of lupeol, acteoside, catalposide, and $5 \mathrm{H} 2 \mathrm{~F}$ was fixed at $280 \mathrm{~nm}$, and lobetyolin and syringaldehyde were analyzed in the wavelength of 310 and $254 \mathrm{~nm}$, respectively [25].

\subsubsection{Preparation of Standard Solutions}

Appropriate amounts of AR components (lupeol, lobetyolin, and syringaldehyde), Rehmanniae Radix Crudus components (containing acteoside, catalposide, and 5-hydroxymethyl2-furfural (5H2F)), and Ginseng Radix Alba component (ginsenoside Rg3 (Rg3)) were measured accurately and dissolved in dimethyl sulfoxide (DMSO) or $\mathrm{MeOH}$ to prepare standard stock solutions with a concentration of $1 \mu \mathrm{g} / \mathrm{mL}$. Next, appropriate amounts of standard solutions were diluted in $\mathrm{MeOH}$ to prepare three different concentrations 1, 5 , and $10 \mathrm{ng} / \mathrm{mL}$. The standard curve of each compound was determined with a coefficient $\left(R^{2}\right)$ value of more than 0.999 . For standard preparations, lobetyolin was purchased from the Extrasynthese (Genay Cedex, France) and all the other standards were from Sigma-Aldrich LLC.

\subsubsection{Preparation of Test Samples for UPLC Analysis}

For the quantitative analysis, $1 \mathrm{~g}$ of the samples were added to $10 \mathrm{~mL}$ of $30 \% \mathrm{MeOH}$ and then microwave extraction was performed for $1 \mathrm{~h}$. The supernatant was filtered using a membrane filter paper of $0.2 \mu \mathrm{m}$ in diameter. The filtered liquid was selected for UPLC analysis.

\subsubsection{Phytochemical Quantification by UPLC}

Lupeol, lobetyolin, syringaldehyde acteoside, catalposide, $5 \mathrm{H} 3 \mathrm{~F}$, and $\mathrm{Rg} 3$ contents in $\mathrm{AR}, \mathrm{KOG}$, and SKOG were quantified using UPLC. The column was kept at $20{ }^{\circ} \mathrm{C}$ for the analysis. In the PDA analysis, lupeol, acteoside, catalposide, and 5H2F were analyzed at a wavelength of $280 \mathrm{~nm}$, whereas lobetyolin and syringaldehyde were analyzed at 310 and $254 \mathrm{~nm}$, respectively. The mobile phase was water and acetonitrile with formic acid $(0.1 \%)$. $\mathrm{Rg} 3$ was analyzed at the wavelength of $203 \mathrm{~nm}$ and the mobile phase was a mixture of water and acetonitrile. A $2 \mu \mathrm{L}$ of the sample was injected into UPLC with a flow rate of $0.4 \mathrm{~mL} / \mathrm{min}$. Phytochemicals of the injected sample were identified by the retention time and the same detectable wavelength value and quantified by measuring the area of the peak (Figure S1).

\subsection{Antitussive Assay}

\subsubsection{Rodents and Husbandry}

The Institute of Cancer Research (ICR) male mice, weighing 29-32 g upon received, were bought from OrientBio, Seungnum, Korea. Four mice were allocated to each cage and housed at the temperature of $20-25^{\circ} \mathrm{C}$ and relative humidity of $50-55 \%$ in a controlled room of 12/12 h (light/dark) cycle, with free access to ad libitum of pelleted food (cat. no. 38057; Purinafeed, Seungnam, Korea) and water. After 7 days of adaptation, all the animals were selected for antitussive experiments, maintained as per the rules and regulations of national usage and welfare of laboratory animals based on ethical principles. 


\subsubsection{Treatment and Grouping}

After a week of adaptation, the eligible rodents were randomly chosen and divided into 8 groups of 10 rodents each, including an intact vehicle control (distilled water (DW), orally administered at $10 \mathrm{~mL} / \mathrm{kg}$ ), $\mathrm{NH}_{4} \mathrm{OH}$ control (DW and $25 \% \mathrm{NH}_{4} \mathrm{OH}$-induced coughing treated groups), TB [14] (a reference control drug, oral administration at $10 \mathrm{~mL} / \mathrm{kg}$, corresponding to $50 \mathrm{mg} / \mathrm{kg}$ and $25 \% \mathrm{NH}_{4} \mathrm{OH}$-treated groups), $\mathrm{AR}$ (oral administration at $10 \mathrm{~mL} / \mathrm{kg}$, corresponding to $400 \mathrm{mg} / \mathrm{kg}$ and $25 \% \mathrm{NH}_{4} \mathrm{OH}$-treated groups), $\mathrm{KOG}$ (oral administration at $10 \mathrm{~mL} / \mathrm{kg}$, corresponding to $400 \mathrm{mg} / \mathrm{kg}$ and $25 \% \mathrm{NH}_{4} \mathrm{OH}$-treated groups), SKOG400 (oral administration at $10 \mathrm{~mL} / \mathrm{kg}$, corresponding to $400 \mathrm{mg} / \mathrm{kg}$ and $25 \% \mathrm{NH}_{4} \mathrm{OH}$ treated groups), SKOG200 (oral administration at $10 \mathrm{~mL} / \mathrm{kg}$, corresponding to $200 \mathrm{mg} / \mathrm{kg}$ and $25 \% \mathrm{NH}_{4} \mathrm{OH}$-treated groups), and SKOG100 (oral administration at $10 \mathrm{~mL} / \mathrm{kg}$, corresponding to $100 \mathrm{mg} / \mathrm{kg}$ and $25 \% \mathrm{NH}_{4} \mathrm{OH}$-treated groups). SKOG was dissolved in DW to make working concentrations of 40,20, and $10 \mathrm{mg} / \mathrm{mL}$, and AR and KOG were prepared following the same procedure to make a concentration of $40 \mathrm{mg} / \mathrm{mL}$ for oral administration. Similarly, TB was suspended and prepared in DW to the working concentration of $5 \mathrm{mg} / \mathrm{mL}$. All the treatments were performed once a day for 11 days before the $\mathrm{NH}_{4} \mathrm{OH}$ exposure. To maintain the same restrain stress, DW was administered in all the control groups rather than AR, KOG, SKOG, or TB treatments.

\subsubsection{Body Weight Measurement}

Body weight (BW) changes in the treatment mice were measured once a day using an electronic balance (Precisa Instrument, Dietikon, Switzland) during the entire administration period of AR, KOG, SKOG, or TB. The BW gain was calculated using a formula as follows:

The BW gain after 11 days of oral administration of test substances $=\mathrm{BW}$ at sacrifice$\mathrm{BW}$ at the initial treatment of the test substance ( $\mathrm{g} / \mathrm{head})$.

\subsubsection{Coughing Induction and Monitoring}

Coughing was induced by an inhalation of $25 \% \mathrm{NH}_{4} \mathrm{OH}$ (Sigma-Aldrich LLC), where $0.3 \mathrm{~mL}$ was taken to a $1 \mathrm{~L}$ Erlenmeyer flask and inhaled to mice for $45 \mathrm{~s}$ at $1 \mathrm{~h}$ after the last administration of the test substance. Following the $\mathrm{NH}_{4} \mathrm{OH}$ induction, the number of coughing responses was quantitated in 6 min using video observations [21,22]. Mice with an intact vehicle control were exposed to $0.3 \mathrm{~mL}$ saline for $45 \mathrm{~s}$, in replacement of $\mathrm{NH}_{4} \mathrm{OH}$. A cough in mice was characterized as opening the mouth with a sudden expulsion followed by the sound of coughing, contraction of thoracic and abdominal muscles, and shaking of the front body $[20,21]$.

\subsubsection{Histopathology}

After obtaining video images, some portion of the left lateral lobes of individual lungs and trachea consisting of $3 \mathrm{~mm}$ from the thyroid cartilages were isolated and fixed in a solution of $10 \%$ neutral buffered formalin (NBF). The sample was then trimmed, embedded in paraffin, sectioned at 3 4 $\mu \mathrm{m}$ thickness, stained with hematoxylin and eosin (H\&E) for general histopathology examination or with toluidine blue for mast cell examination, and observed under a light microscope (Eclipse 80i; Nikon, Tokyo, Japan). Histopathological profiles were analyzed with an image analysis program (iSolution FL ver 9.1; IMT i-solution Inc., Quebec, QC, Canada), as followed by the previously established methods [25,26].

\subsection{Expectorant Assay}

\subsubsection{Rodents and Husbandry}

ICR mice $\left(\sigma^{7}\right)$ of 86 weeks old, weighing 29-32 g upon their receival, were bought from OrientBio, Seungnum, Korea. Animal husbandry was conducted the same as in the antitussive assay. Mice selected for expectorant experiments were maintained abiding by the rules and regulations of national usage and welfare of laboratory animals based on ethical principles. 


\subsubsection{Treatment and Grouping}

After 7 days of adaptation, 70 mice each were selected and divided into 7 groups each, including an intact vehicle control (DW), AM ( $250 \mathrm{mg} / \mathrm{kg}$ administered mice), AR (administration at $400 \mathrm{mg} / \mathrm{kg}$ and AM-exposed group), KOG (administration at $400 \mathrm{mg} / \mathrm{kg}$ and AM-exposed group), SKOG (administration at $400 \mathrm{mg} / \mathrm{kg}$ and AM-exposed group), SKOG (administration at $200 \mathrm{mg} / \mathrm{kg}$ and AM-exposed group), SKOG (administration at $100 \mathrm{mg} / \mathrm{kg}$ and AM-exposed group). AR, KOG, and SKOG were orally administered the same as in the antitussive assay, once a day for 11 days before being treated with phenol red. To provide the same restrain stress, the intact vehicle control rodents were orally administered $10 \mathrm{~mL} / \mathrm{kg}$ of DW, rather than AR, KOG, SKOG, or AM.

\subsubsection{BW Measurement}

The BW and BW gain were evaluated in a similar way as mentioned in the antitussive assay.

\subsubsection{Measurement of Mucous Secretion}

To measure the mucous secretion, rodents were intraperitoneally injected with a single dose of $5 \%$ phenol red solution (Junsei Chemical Co. Ltd., Tokyo, Japan) at $10 \mathrm{~mL} / \mathrm{kg}$ dissolved in a saline solution $(w / v)$, after $30 \mathrm{~min}$ of the last (eleventh) administration of test material. Gross images of individual mice were then obtained to investigate the phenol red-induced body-surface redness. Thereafter, the trachea was dissected after the sacrifice of mice by cervical dislocation and homogenized in normal saline for $15 \mathrm{~min}$ to prepare the trachea lavage fluid (TLF) after adding $1 \mathrm{~mL}$ of $5 \% \mathrm{NaHCO}_{3}$ solution $(w / v)$. The optical density (OD) of TLF was recorded at the wavelength of $546 \mathrm{~mm}$, as followed by the previous studies $[20,22]$.

\subsubsection{Histopathology}

At trachea excisions, individual left lateral lobes of the lung were collected. Then, the lung lobes were fixed ( $10 \% \mathrm{NBF})$, crossly trimmed, embedded in paraffin, sectioned (3 4 $\mu \mathrm{m}$ thickness), stained (H\&E) for general histopathology examination or with a Periodic acid Schiff stain for mucous-producing cell examination, and observed under a light microscope. Histopathological profiles were examined using an image analysis program, as described formerly [25-28].

\subsection{Anti-Inflammatory Assay}

\subsubsection{Rodents and Husbandry}

ICR mice ( $0^{7}$ )of 96 weeks old, weighing 29-32 g upon their receival, were bought from OrientBio, Seungnum, Korea. Animal husbandry was conducted the same as in the antitussive assay. Mice selected for anti-inflammatory experiments were maintained following the rules and regulations of national usage and welfare of laboratory animals based on ethical principles.

\subsubsection{Treatment and Grouping}

After 7 days of adaptation, 80 mice each were selected and divided into 8 groups each, including an intact vehicle control (DW), xylene control $(0.03 \mathrm{~mL}$ of xylene of topical application to the anterior surface of the right ear), DEXA (administration at $1 \mathrm{mg} / \mathrm{kg}$ and Xylene-exposed group), AR (administration at $400 \mathrm{mg} / \mathrm{kg}$ and xylene-exposed group), KOG (administration at $400 \mathrm{mg} / \mathrm{kg}$ and xylene-exposed group), SKOG (administration at $400 \mathrm{mg} / \mathrm{kg}$ and xylene-exposed group), SKOG (administration at $200 \mathrm{mg} / \mathrm{kg}$ and xyleneexposed group), SKOG (administration at $100 \mathrm{mg} / \mathrm{kg}$ and xylene-exposed group). AR, KOG, and SKOG were orally administered the same as in the antitussive and expectorant experiments, once a day for 11 days before the xylene treatment. To provide the same restrain stress, the intact vehicle control rodents were orally administered at $10 \mathrm{~mL} / \mathrm{kg}$ of DW, rather than AR, KOG, SKOG, or xylene. 


\subsubsection{BW Measurement}

BW and BW gain were determined in the same procedure as mentioned in the antitussive assays.

\subsubsection{Ear Weight Measurement}

After the xylene treatment for $2 \mathrm{~h}$, circular sections of the ear were collected and weighed as the absolute ear wet-weight. The relative ear weight (\% of BW) was measured to reduce the differences of individuals using a formula as given below:

Relative ear weight $(\%$ of $\mathrm{BW})=($ absolute ear wet-weight $/ \mathrm{BW}$ at sacrifice $) \times 100$

\subsubsection{Histopathology}

Individual ear samples were fixed in $10 \% \mathrm{NBF}$, crossly trimmed, embedded in paraffin, sectioned (to $3 \sim 4 \mu \mathrm{m}$ thickness), and stained (H\&E) for general histopathology examination or with toluidine blue for mast cell examination. Histopathological profiles were analyzed with an image analysis software program, as described in previous studies $[23,25,26,29]$.

\subsection{Statistical Analyses}

All data were shown as the mean \pm standard deviation (SD) of six measurements, whereas data related to the rodent experiments were eight mice in each experiment. All the statistical analyses were performed by Statistical Package for the Social Sciences (SPSS) (14.0K; IBM SPSS Inc., Armonk, NY, USA), where the statistical difference was $p$-value of $<0.05$, followed by the methods of Hu et al. [14].

\section{Results}

\subsection{Contents of Specific Compounds of SKOG}

Lobetyolin, lupeol, and syringaldehyde were detected in AR at $6.99 \pm 0.24$, $2029.00 \pm 1.96$, and $0.26 \pm 0.03 \mathrm{mg} / \mathrm{kg}$ of fresh weight (FW), respectively. 5H2F, acteoside, catalposide, and Rg3 were detected in KOG at $628.26 \pm 13.2,0.33 \pm 0.02,0.41 \pm 0.03$, and $7.27 \pm 0.46 \mathrm{mg} / \mathrm{kg}(\mathrm{FW})$, respectively. Lupeol, syringaldehyde, $5 \mathrm{H} 2 \mathrm{~F}$, acteoside, catalposide, and Rg3 were detected in SKOG at $224.52 \pm 12.5,0.14 \pm 0.01,559.50 \pm 1.70$, $0.31 \pm 0.01,0.33 \pm 0.01$, and $4.42 \pm 0.02 \mathrm{mg} / \mathrm{kg}(\mathrm{FW})$, respectively. These results were obtained from the UPLC analysis, as presented in Figure S1.

\subsection{Antitussive Assay}

\subsubsection{Changes in BW and BW Gain}

Following the oral administration, the $\mathrm{NH}_{4} \mathrm{OH}$ control mice had no effects on $\mathrm{BW}$ and BW gain as compared with those rodents of the intact vehicle control group. Similarly, AR and KOG $400 \mathrm{mg} / \mathrm{kg}$, TB $50 \mathrm{mg} / \mathrm{kg}$, and SKOG 400, 200, and $100 \mathrm{mg} / \mathrm{kg}$ observed no significant changes in $\mathrm{BW}$ and $\mathrm{BW}$ gain when compared with the $\mathrm{NH}_{4} \mathrm{OH}$ control mice, respectively. The results of BW and BW gain in the rodentstreated with SKOG 400, 200, and $100 \mathrm{mg} / \mathrm{kg}$ were non-significant, compared with the AR and KOG $400 \mathrm{mg} / \mathrm{kg}$ groups (Table A1).

\subsubsection{Changes in the Coughing Frequency}

Due to the exposure of $\mathrm{NH}_{4} \mathrm{OH}$ in mice, the number of coughing responses was significantly increased when compared with the intact vehicle control mice $(p<0.01)$. However, dose-dependent and significant decreases $(p<0.01)$ in the number of coughing responses were seen with mice treated with SKOG 400, 200, and $100 \mathrm{mg} / \mathrm{kg}$ as compared to the $\mathrm{NH}_{4} \mathrm{OH}$ control mice. Similar results were found in the treatment of a group of $\mathrm{AR}$ and KOG $400 \mathrm{mg} / \mathrm{kg}$ and TB $50 \mathrm{mg} / \mathrm{kg}$ showing a significant decrease $(p<0.01)$ in coughing responses, compared with the $\mathrm{NH}_{4} \mathrm{OH}$ control mice. Moreover, decreased numbers of the coughing response were significantly $(p<0.01)$ higher in SKOG 400 and $200 \mathrm{mg} / \mathrm{kg}$ treatment groups than those of mice treated with AR and KOG $400 \mathrm{mg} / \mathrm{kg}$. Other findings revealed that AR and KOG $400 \mathrm{mg} / \mathrm{kg}$ and SKOG $100 \mathrm{mg} / \mathrm{kg}$ treatment were found to be 
similar or more favorable to the effects of $\mathrm{TB} 50 \mathrm{mg} / \mathrm{kg}$ against $\mathrm{NH}_{4} \mathrm{OH}$-induced coughing responses (Figure 1).

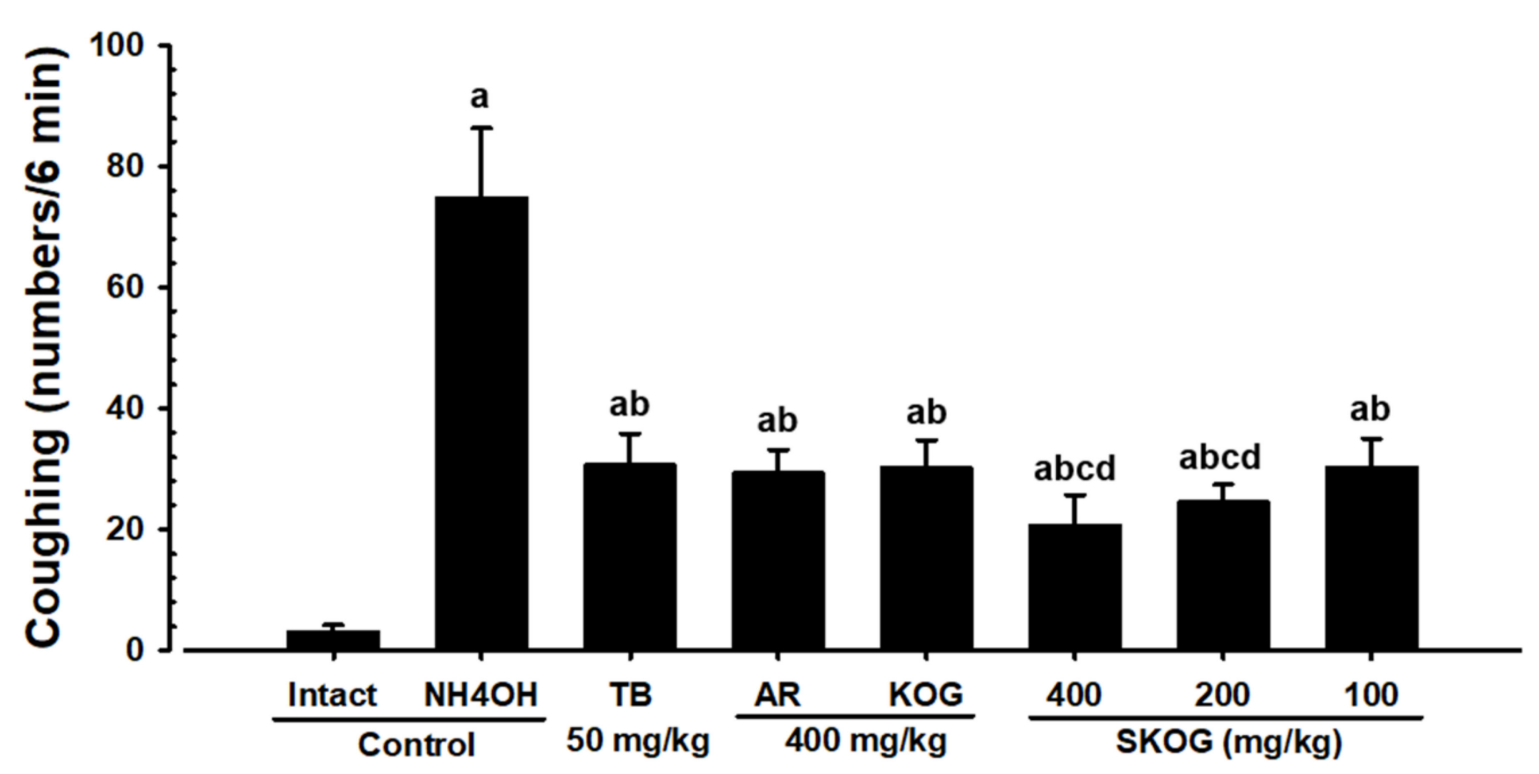

Figure 1. Effects of adenophorae radix powder (AR), kyeongok-go (KOG), and shashamkyeongok-go (SKOG) on the changes of coughing frequencies in $\mathrm{NH}_{4} \mathrm{OH}$-induced coughing mice. Values are expressed as the mean $\pm \mathrm{SD}$ of 10 mice. Different letters indicate statistical significance. Treatment groups expressed as ${ }^{\mathrm{a}} p<0.01,{ }^{\mathrm{b}} p<0.01,{ }^{\mathrm{c}} p<0.01$, and ${ }^{\mathrm{d}} p<0.01$ compared with the intact vehicle control, $\mathrm{NH}_{4} \mathrm{OH}$ control, AR $400 \mathrm{mg} / \mathrm{kg}$, and $\mathrm{KOG} 400 \mathrm{mg} / \mathrm{kg}$ by the Mann-Whitney U (MW) test, respectively.

\subsubsection{Histopathological Findings of the Trachea and Lung}

Significant decreases $(p<0.01)$ in the tracheal lumen diameter and ASA, as well as increases in the thickness of the total tracheal wall, epithelium, and submucosa; the number of infiltrated inflammatory and mast cells in the trachea; thicknesses of the alveolar septum; and the number of inflammatory cells between the alveolar septum were observed in $\mathrm{NH}_{4} \mathrm{OH}$ treated mice. However, these $\mathrm{NH}_{4} \mathrm{OH}$-induced allergic acute inflammation-related histopathological findings were significantly inhibited $(p<0.01)$ by the pre-treatment of SKOG 400, 200, and $100 \mathrm{mg} / \mathrm{kg}$ in a dose-dependent manner, compared with those in the $\mathrm{NH}_{4} \mathrm{OH}$-induced control rodents. In addition, the mice treated with $\mathrm{AR}$ and $\mathrm{KOG}$ $400 \mathrm{mg} / \mathrm{kg}$ and TB $50 \mathrm{mg} / \mathrm{kg}$ significantly reduced $(p<0.01)$ the $\mathrm{NH}_{4} \mathrm{OH}$-induced allergic acute inflammation in histopathological observations, compared with those in the $\mathrm{NH}_{4} \mathrm{OH}$ induced control rodents. Especially, the mice treated with SKOG 400 and $200 \mathrm{mg} / \mathrm{kg}$ significantly $(p<0.01$ or $p<0.05)$ decreased the $\mathrm{NH}_{4} \mathrm{OH}$-induced allergic acute inflammation, compared with those in the mice fed with AR and KOG $400 \mathrm{mg} / \mathrm{kg}$. Moreover, SKOG $100 \mathrm{mg} / \mathrm{kg}$ showed favorable inhibitory effects similar to those of AR and KOG $400 \mathrm{mg} / \mathrm{kg}$ on $\mathrm{NH}_{4} \mathrm{OH}$-induced allergic acute inflammation. In addition, AR and KOG $400 \mathrm{mg} / \mathrm{kg}$ and SKOG $100 \mathrm{mg} / \mathrm{kg}$ observed inhibitory effects similar to or more favorable than those of $\mathrm{TB} 50 \mathrm{mg} / \mathrm{kg}$ on $\mathrm{NH}_{4} \mathrm{OH}$-treated groups (Tables 1 and 2, Figures 2 and 3). 
Table 1. Effects of AR, KOG, and SKOG on the histomorphometry of trachea in mice.

\begin{tabular}{|c|c|c|c|c|c|c|}
\hline \multirow{2}{*}{$\begin{array}{l}\text { Index } \\
\text { Groups }\end{array}$} & \multirow{2}{*}{$\begin{array}{l}\text { Diameter of Lumen } \\
(\mu \mathrm{m})\end{array}$} & \multicolumn{3}{|c|}{ Thickness $(\mu \mathrm{m})$} & \multicolumn{2}{|c|}{ Cells (Numbers $/ \mathrm{mm}^{2}$ ) } \\
\hline & & Total Wall & Epithelium & Submucosa & Inflammatory & Mast \\
\hline \multicolumn{7}{|l|}{ Controls } \\
\hline Intact & $1177.86 \pm 130.95$ & $161.47 \pm 15.34$ & $14.38 \pm 2.91$ & $26.68 \pm 4.85$ & $21.40 \pm 12.21$ & $1.20 \pm 0.79$ \\
\hline $\mathrm{NH}_{4} \mathrm{OH}$ & $658.57 \pm 106.44^{\mathrm{a}}$ & $220.38 \pm 13.45^{h}$ & $37.53 \pm 9.48^{h}$ & $89.73 \pm 10.46^{h}$ & $449.30 \pm 102.75^{h}$ & $38.70 \pm 11.66^{h}$ \\
\hline \multicolumn{7}{|l|}{ Reference } \\
\hline TB $50 \mathrm{mg} / \mathrm{kg}$ & $860.11 \pm 100.75^{\mathrm{ac}}$ & $191.23 \pm 10.24 \mathrm{hi}$ & $24.21 \pm 4.36^{\mathrm{hi}}$ & $47.31 \pm 11.39 \mathrm{hi}$ & $167.40 \pm 40.26^{\mathrm{hi}}$ & $14.30 \pm 4.60 \mathrm{hi}$ \\
\hline $\mathrm{AR} 400 \mathrm{mg} / \mathrm{kg}$ & $934.14 \pm 104.43^{\mathrm{ac}}$ & $185.59 \pm 10.94 \mathrm{hi}$ & $23.07 \pm 3.32 \mathrm{hi}$ & $44.99 \pm 6.09 \mathrm{hi}$ & $62.70 \pm 37.57 \mathrm{hi}$ & $8.60 \pm 2.27 \mathrm{hi}$ \\
\hline $\begin{array}{c}\text { KOG } 400 \mathrm{mg} / \mathrm{kg} \\
\text { SKOG }\end{array}$ & $934.89 \pm 83.13^{\mathrm{ac}}$ & $186.21 \pm 11.10^{\mathrm{hi}}$ & $23.87 \pm 2.38$ hi & $40.31 \pm 6.64 \mathrm{hi}$ & $184.10 \pm 20.32 \mathrm{hi}$ & $8.40 \pm 1.51 \mathrm{hi}$ \\
\hline $400 \mathrm{mg} / \mathrm{kg}$ & $1087.76 \pm 118.72 b b^{b c d f}$ & $171.56 \pm 7.07^{\mathrm{ikm}}$ & $18.92 \pm 2.14$ hikm & $30.30 \pm 3.24^{\mathrm{ikm}}$ & $85.50 \pm 19.82$ hikm & $1.80 \pm 1.03^{i k m}$ \\
\hline $200 \mathrm{mg} / \mathrm{kg}$ & $1036.55 \pm 76.84$ aceg & $175.45 \pm 5.03^{\text {iln }}$ & $19.74 \pm 1.37$ hikm & $32.71 \pm 3.79$ hikm & $120.70 \pm 20.94$ hikm & $3.70 \pm 1.34$ hikm \\
\hline $100 \mathrm{mg} / \mathrm{kg}$ & $936.74 \pm 70.89$ ac & $185.19 \pm 7.57 \mathrm{hi}$ & $23.76 \pm 3.34 \mathrm{hi}$ & $42.41 \pm 8.60 \mathrm{hi}$ & $177.60 \pm 26.02 \mathrm{hi}$ & $8.70 \pm 2.16$ hi \\
\hline
\end{tabular}

Values are presented as the mean $\pm \mathrm{SD}$ of 10 mice. Different letters indicate statistical significance. Treatment groups expressed as ${ }^{\mathrm{a}} p<0.01$ and ${ }^{\mathrm{b}} p<0.05,{ }^{\mathrm{c}} p<0.01,{ }^{\mathrm{d}} p<0.01$ and ${ }^{\mathrm{e}} p<0.05$, and ${ }^{\mathrm{f}} p<0.01$ and ${ }^{\mathrm{g}} p<0.05$ compared with the intact control, $\mathrm{NH}_{4} \mathrm{OH}$ control, AR $400 \mathrm{mg} / \mathrm{kg}$, and KOG $400 \mathrm{mg} / \mathrm{kg}$ by the least-significant differences multi-comparison (LSD) test, respectively. Moreover, treatment groups showed ${ }^{\mathrm{h}} p<0.01,{ }^{\mathrm{i}} p<0.01,{ }^{\mathrm{k}} p<0.01$ and ${ }^{\mathrm{l}} p<0.05$, and ${ }^{\mathrm{m}} p<0.01$ and ${ }^{\mathrm{n}} p<0.05$ compared with the intact control, $\mathrm{NH}_{4} \mathrm{OH}$ control, AR $400 \mathrm{mg} / \mathrm{kg}$, and KOG $400 \mathrm{mg} / \mathrm{kg}$ by the MW test, respectively.

Table 2. Effects of AR, KOG, and SKOG on the histomorphometry of lung-alveolar regions in mice.

\begin{tabular}{|c|c|c|c|}
\hline $\begin{array}{l}\text { Index } \\
\text { Groups }\end{array}$ & $\begin{array}{c}\text { Alveolar Surface Area } \\
(\%)\end{array}$ & $\begin{array}{l}\text { Septum Thickness } \\
(\mu \mathrm{m})\end{array}$ & $\begin{array}{c}\text { Inflammatory Cells } \\
\text { (Numbers/mm²) }\end{array}$ \\
\hline \multicolumn{4}{|l|}{ Controls } \\
\hline Intact & $78.87 \pm 9.31$ & $7.32 \pm 1.45$ & $60.20 \pm 19.63$ \\
\hline $\mathrm{NH}_{4} \mathrm{OH}$ & $30.94 \pm 9.58^{a}$ & $72.41 \pm 10.80^{g}$ & $1886.70 \pm 394.17^{\mathrm{g}}$ \\
\hline \multicolumn{4}{|l|}{ Reference } \\
\hline TB $50 \mathrm{mg} / \mathrm{kg}$ & $51.13 \pm 5.95^{\mathrm{ac}}$ & $30.53 \pm 10.06^{\mathrm{gh}}$ & $492.00 \pm 114.18^{g h}$ \\
\hline $\mathrm{AR} 400 \mathrm{mg} / \mathrm{kg}$ & $53.83 \pm 7.88^{\mathrm{ac}}$ & $27.22 \pm 7.28 \mathrm{gh}$ & $453.80 \pm 104.35 \mathrm{gh}$ \\
\hline $\begin{array}{c}\text { KOG } 400 \mathrm{mg} / \mathrm{kg} \\
\text { SKOG }\end{array}$ & $52.34 \pm 8.24^{\mathrm{ac}}$ & $27.98 \pm 3.75 \mathrm{gh}$ & $492.60 \pm 118.49 \mathrm{gh}$ \\
\hline $400 \mathrm{mg} / \mathrm{kg}$ & $71.32 \pm 5.65 \mathrm{bcdf}$ & $12.56 \pm 2.52$ ghik & $234.20 \pm 42.55$ ghik \\
\hline $200 \mathrm{mg} / \mathrm{kg}$ & $62.29 \pm 6.45^{\text {acef }}$ & $20.26 \pm 3.12$ ghik & $347.60 \pm 79.19$ ghjk \\
\hline $100 \mathrm{mg} / \mathrm{kg}$ & $53.36 \pm 9.65^{\mathrm{ac}}$ & $27.99 \pm 6.85^{\mathrm{gh}}$ & $481.90 \pm 132.69 \mathrm{gh}$ \\
\hline
\end{tabular}

Values are presented as the mean \pm SD of 10 mice. Different letters indicate statistical significance. Treatment groups expressed as ${ }^{a} p<0.01$ and ${ }^{\mathrm{b}} p<0.05,{ }^{\mathrm{c}} p<0.01,{ }^{\mathrm{d}} p<0.01$ and ${ }^{\mathrm{e}} p<0.05,{ }^{\mathrm{f}} p<0.01$ compared with the intact control, $\mathrm{NH}_{4} \mathrm{OH}$ control, AR $400 \mathrm{mg} / \mathrm{kg}$, and KOG $400 \mathrm{mg} / \mathrm{kg}$ by the LSD test, respectively. Moreover, treatment groups showed ${ }^{\mathrm{g}} p<0.01,{ }^{\mathrm{h}} p<0.01,{ }^{\mathrm{i}} p<0.01$ and ${ }^{\mathrm{j}} p<0.05,{ }^{\mathrm{k}} p<0.01$ compared with the intact control, $\mathrm{NH}_{4} \mathrm{OH}$ control, $\mathrm{AR} 400 \mathrm{mg} / \mathrm{kg}$, and $\mathrm{KOG} 400 \mathrm{mg} / \mathrm{kg}$ by the MW test, respectively. 
Hematoxylin-Eosin stain

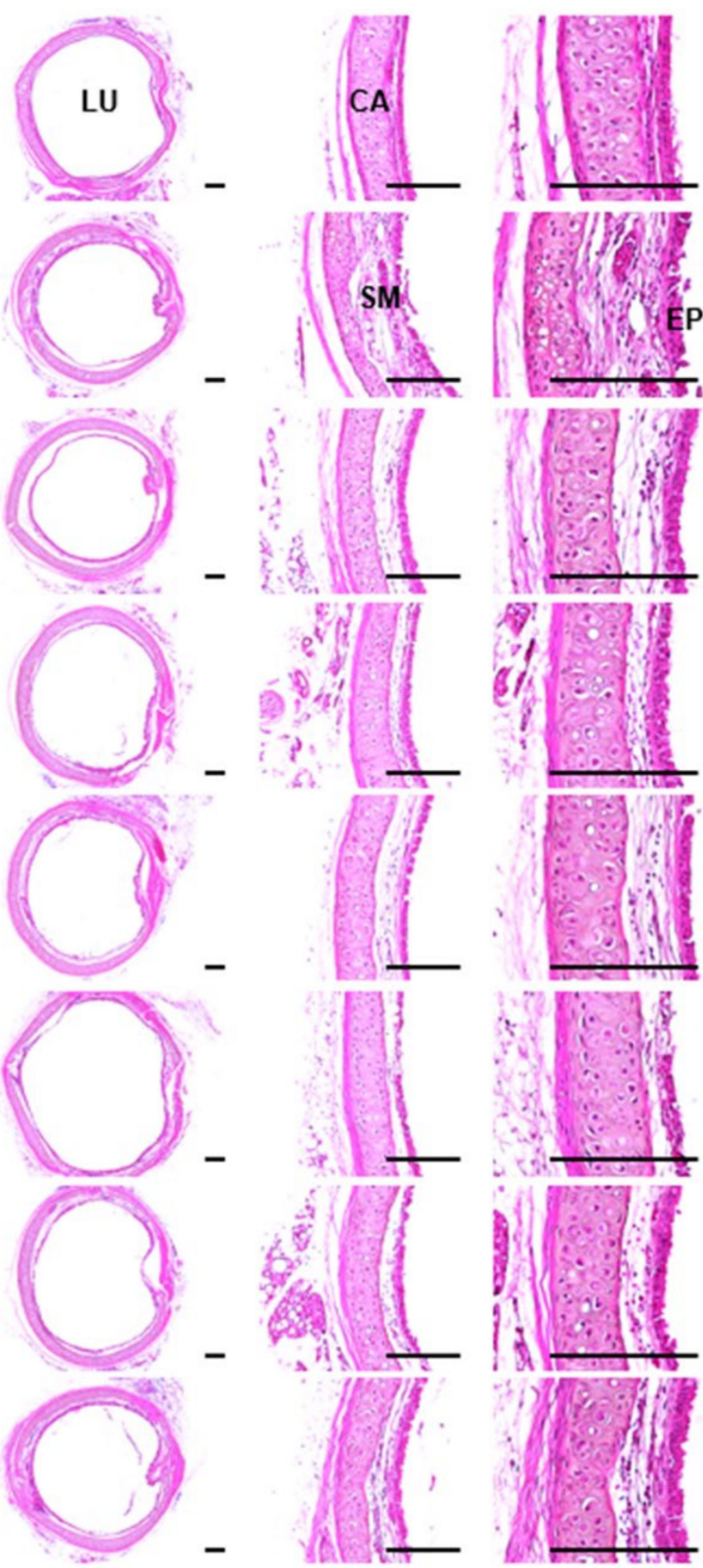

Toludine blue stain

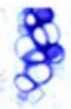

-A-

$$
\because
$$

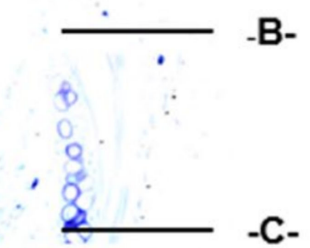

-C-

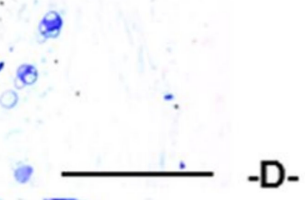

-D-

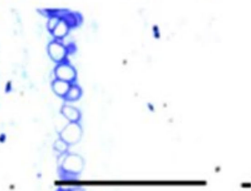

-E-

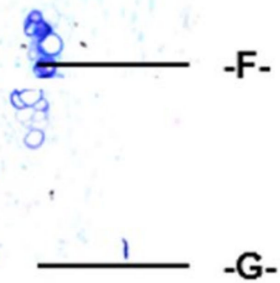

$-G-$

$-\mathrm{H}-$

Figure 2. Changes in the histological features of trachea in mice. Different treatment groups as followed by the (A) intact vehicle control, (B) $\mathrm{NH}_{4} \mathrm{OH}$ control, (C) TB $50 \mathrm{mg} / \mathrm{kg}+\mathrm{NH}_{4} \mathrm{OH}$, (D) AR $400 \mathrm{mg} / \mathrm{kg}+\mathrm{NH}_{4} \mathrm{OH},\left(\right.$ E) KOG $400 \mathrm{mg} / \mathrm{kg}+\mathrm{NH}_{4} \mathrm{OH},(\mathbf{F}) \mathrm{SKOG} 400 \mathrm{mg} / \mathrm{kg}+\mathrm{NH}_{4} \mathrm{OH},(\mathbf{G}) \mathrm{SKOG}$ $200 \mathrm{mg} / \mathrm{kg}+\mathrm{NH}_{4} \mathrm{OH}$, and (H) SKOG $100 \mathrm{mg} / \mathrm{kg}+\mathrm{NH}_{4} \mathrm{OH}$. Scale bar = $120 \mu \mathrm{m}$. LU: Lumen; CA: Cartilages; SM: Submucosa; EP: Epithelium. 


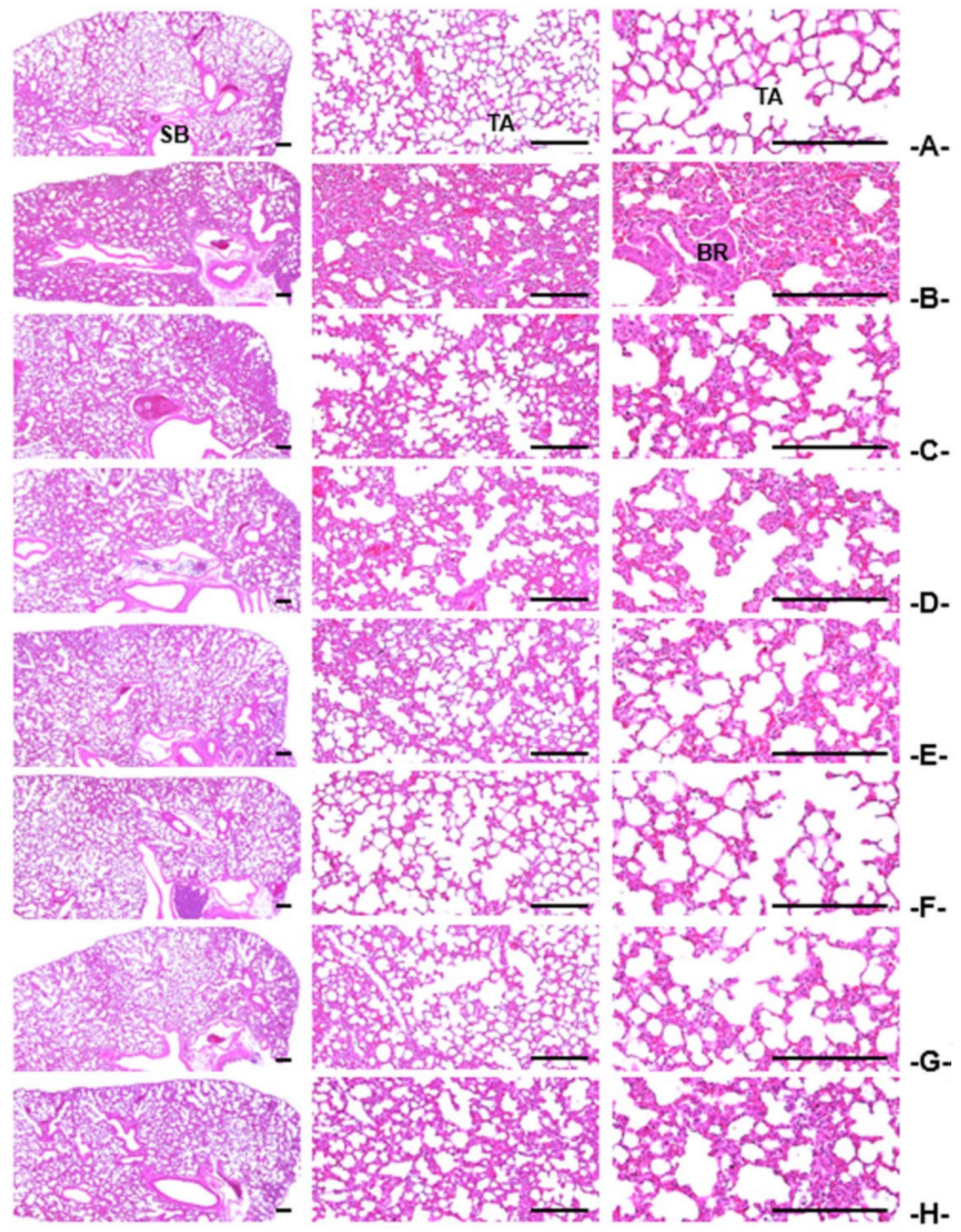

Figure 3. Changes in the histological features of lung in mice. Different treatment groups as followed by the (A) intact vehicle control, (B) $\mathrm{NH}_{4} \mathrm{OH}$ control, (C) TB $50 \mathrm{mg} / \mathrm{kg}+\mathrm{NH}_{4} \mathrm{OH}$, (D) AR $400 \mathrm{mg} / \mathrm{kg}$ $+\mathrm{NH}_{4} \mathrm{OH},(\mathrm{E}) \mathrm{KOG} 400 \mathrm{mg} / \mathrm{kg}+\mathrm{NH}_{4} \mathrm{OH},(\mathbf{F}) \mathrm{SKOG} 400 \mathrm{mg} / \mathrm{kg}+\mathrm{NH}_{4} \mathrm{OH},(\mathrm{G}) \mathrm{SKOG} 200 \mathrm{mg} / \mathrm{kg}+$ $\mathrm{NH}_{4} \mathrm{OH}$, and (H) SKOG $100 \mathrm{mg} / \mathrm{kg}+\mathrm{NH}_{4} \mathrm{OH}$. Scale bar $=120 \mu \mathrm{m}$. SB: Secondary bronchus; TA: Alveolus-terminal bronchiole; TB: Theobromine; ASA: Alveolar surface area; BR: Bronchus.

\subsection{Expectorant Assay}

\subsubsection{Changes in BW and BW Gain}

Following 11 days of oral administration, the results of BW and BW gain showed no significant changes in different treatment groups of AM $250 \mathrm{mg} / \mathrm{kg}$, AR and KOG $400 \mathrm{mg} / \mathrm{kg}$, SKOG 400, 200, and $100 \mathrm{mg} / \mathrm{kg}$ when compared with the intact vehicle control mice, respectively. Similarly, rodents treated with SKOG 400, 200, and $100 \mathrm{mg} / \mathrm{kg}$ had no significant difference in BW and BW gain, respectively, compared with AR and KOG $400 \mathrm{mg} / \mathrm{kg}$ (Table A2). 


\subsubsection{Body-Surface Gross Findings}

An experiment was set to elucidate the expectorant effect of SKOG 400, 200, and $100 \mathrm{mg} / \mathrm{kg}$ that showed noticeable and dose-dependent increases of body surface redness, compared with the intact vehicle control rodents, which indicates an increased uptake and secretion of intraperitoneally injected phenol red. Moreover, AR and KOG mg/kg and AM $250 \mathrm{mg} / \mathrm{kg}$ dramatically increased the secretion of phenol red after $30 \mathrm{~min}$ of intraperitoneal injection as compared with the intact vehicle control. Of note, SKOG 400 and $200 \mathrm{mg} / \mathrm{kg}$ had obvious increases of phenol red secretion with a gross sign of body surface redness, while the treatment with AR and KOG $400 \mathrm{mg} / \mathrm{kg}$, and the results were more similar to or favorable than those of AM $250 \mathrm{mg} / \mathrm{kg}$ fed rodents (Figure S2).

\subsubsection{Changes in Mucous Secretion}

Mice treated with AR and KOG $400 \mathrm{mg} / \mathrm{kg}$, AM $250 \mathrm{mg} / \mathrm{kg}$, and SKOG 400, 200, and $100 \mathrm{mg} / \mathrm{kg}$ showed dose-dependent and significant increases $(p<0.01)$ in the OD values of TLF, compared with the intact vehicle control rodents after $30 \mathrm{~min}$ of phenol red injection, which indicated an increase in the mucous secretion in the trachea. Moreover, SKOG 400 and $200 \mathrm{mg} / \mathrm{kg}$ significantly exhibited $(p<0.01)$ OD values of TLF as compared with AR and KOG $400 \mathrm{mg} / \mathrm{kg}$, respectively, and the results were similar to or more favorable than those rodents fed with AM $250 \mathrm{mg} / \mathrm{kg}$ (Figure 4).

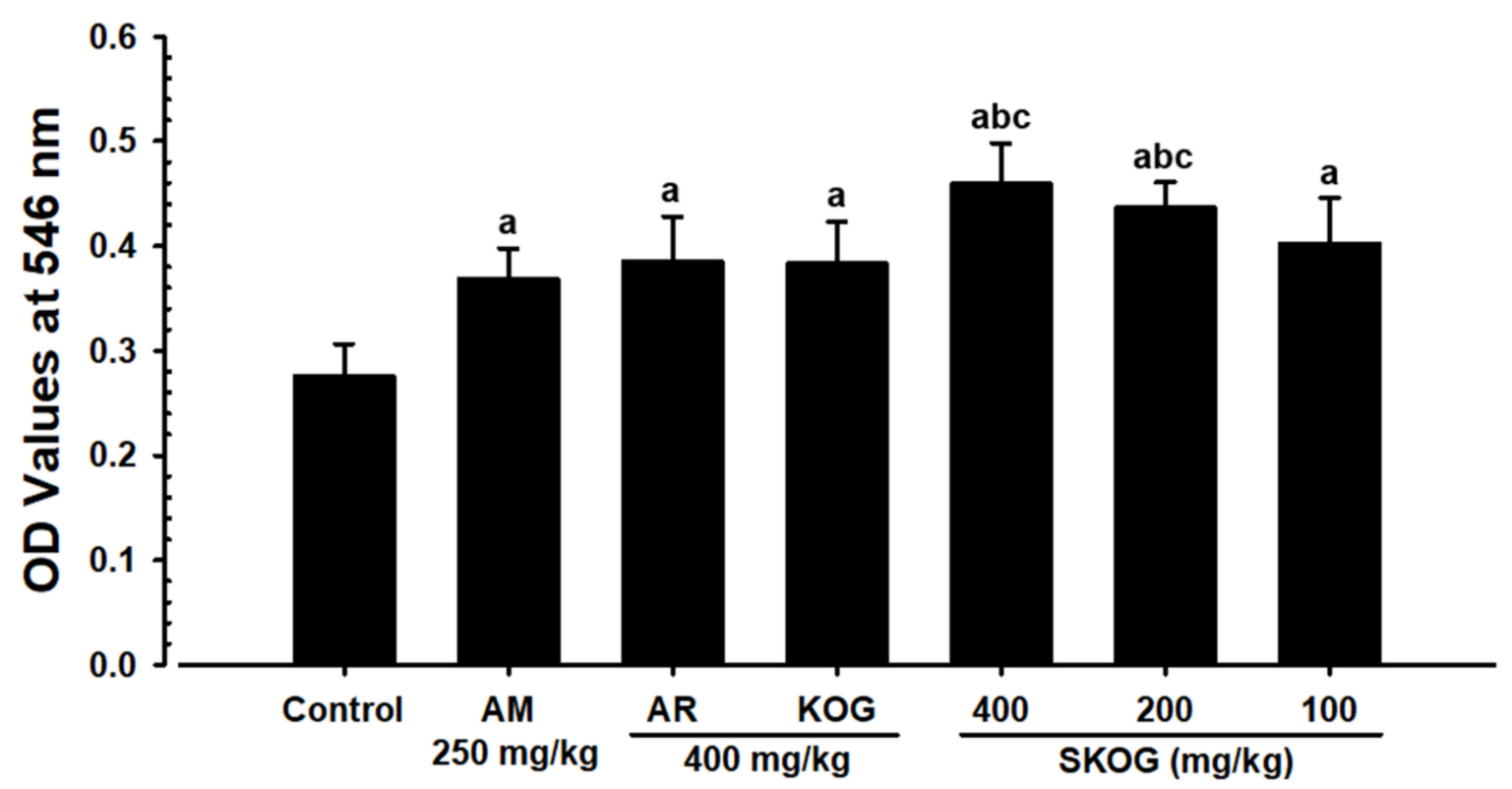

Figure 4. Effects of AR, KOG, and SKOG on mucous secretions in the trachea of mice. Values are shown as the mean \pm SD of 10 mice. Different letters indicate statistical significance. Treatment groups expressed as ${ }^{\mathrm{a}} p<0.01,{ }^{\mathrm{b}} p<0.01$, and ${ }^{c} p<0.01$ compared with the intact vehicle control, AR $400 \mathrm{mg} / \mathrm{kg}$, and KOG $400 \mathrm{mg} / \mathrm{kg}$ by the LSD test, respectively.

\subsubsection{Histopathological Findings in the Intrapulmonary Secondary Bronchus}

The administration of mice with SKOG 400, 200, and $100 \mathrm{mg} / \mathrm{kg}$ resulted in a dosedependent and significant increase $(p<0.01$ or $p<0.05)$ in the thickness of intrapulmonary secondary bronchus mucosa and the number of PAS-positive mucous-producing cells, respectively, compared with those mice in the vehicle control, suggesting an ability to increase the mucous secretion and activity of bronchus mucosa. Moreover, AR and KOG $400 \mathrm{mg} / \mathrm{kg}$ and AM $250 \mathrm{mg} / \mathrm{kg}$ administered mice showed similar significant $(p<0.01)$ effects as compared with the intact vehicle control. Compared with AR and KOG $400 \mathrm{mg} / \mathrm{kg}$, mice with SKOG 400 and $200 \mathrm{mg} / \mathrm{kg}$ treatment groups showed a significant increase of thickness of intrapulmonary secondary bronchus mucosa and the number of PAS-positive 
mucous-producing cells, respectively. The results were similar to or more favorable than the mice with the treatment of AM $250 \mathrm{mg} / \mathrm{kg}$ (Figures 5 and 6).
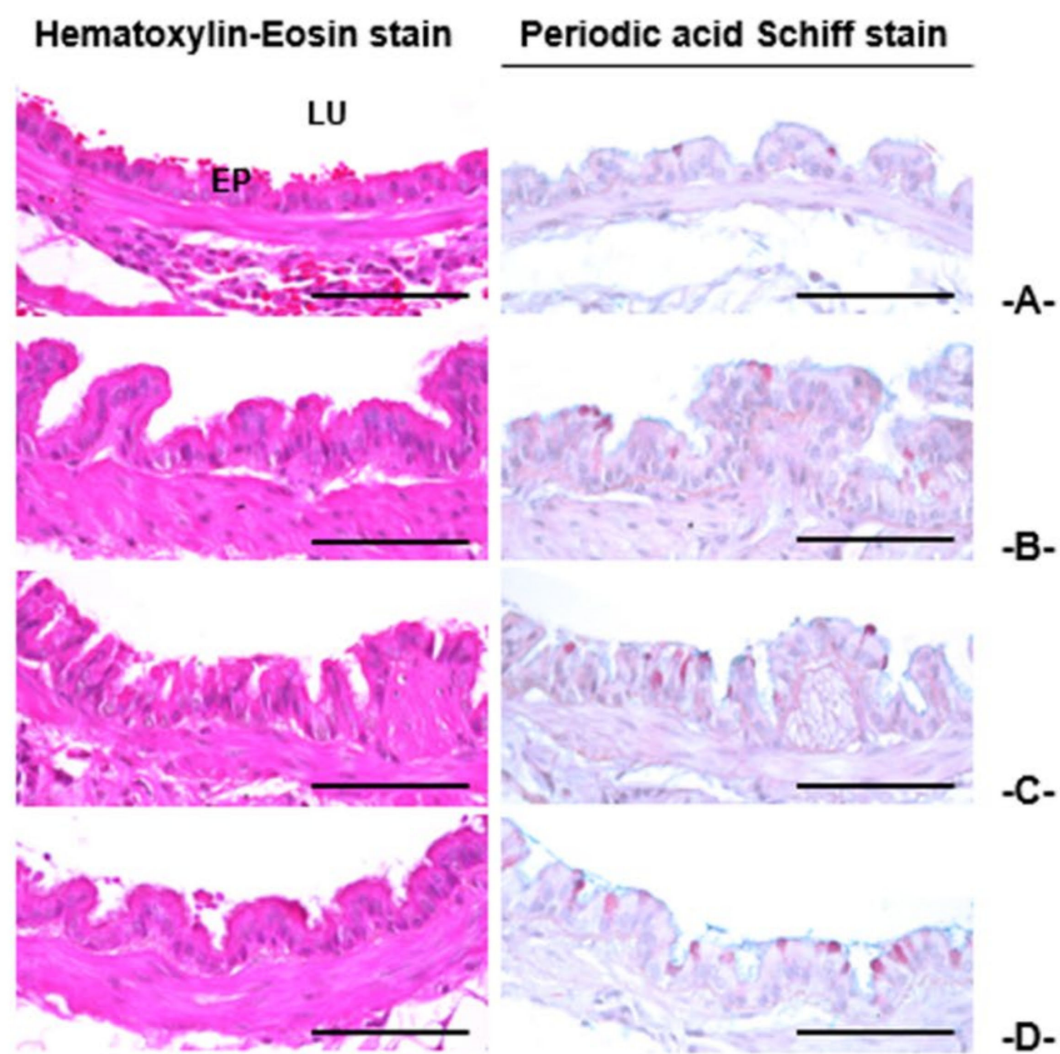

-D-
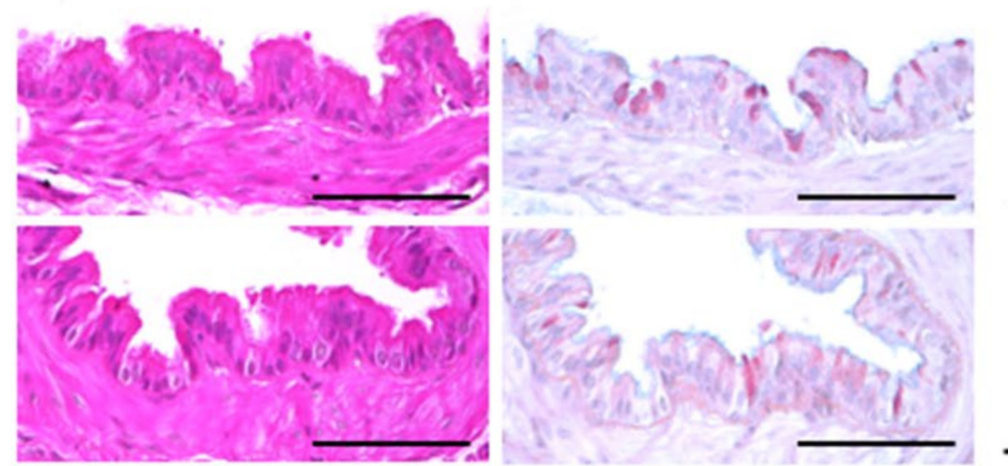

-E-
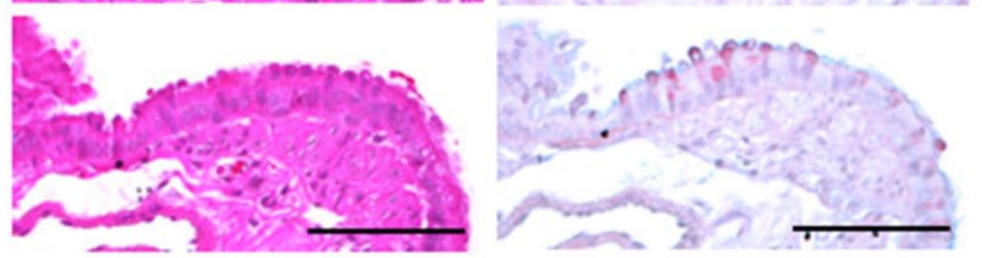

$-\mathrm{F}-$

-G-

Figure 5. Changes in the histological features of intrapulmonary secondary bronchus in mice. Different treatment groups as followed by the (A) intact vehicle control, (B) AM $250 \mathrm{mg} / \mathrm{kg}$, (C) AR $400 \mathrm{mg} / \mathrm{kg}$, (D) KOG $400 \mathrm{mg} / \mathrm{kg}$, (E) SKOG $400 \mathrm{mg} / \mathrm{kg}$, (F) SKOG 200 mg $/ \mathrm{kg}$, (G) SKOG 100 mg/kg. Scale bar $=60 \mu \mathrm{m}$. AM: Ambroxol; EP: Epithelium; LU: Lumen; PAS: Periodic Acid Schiff Stain. 


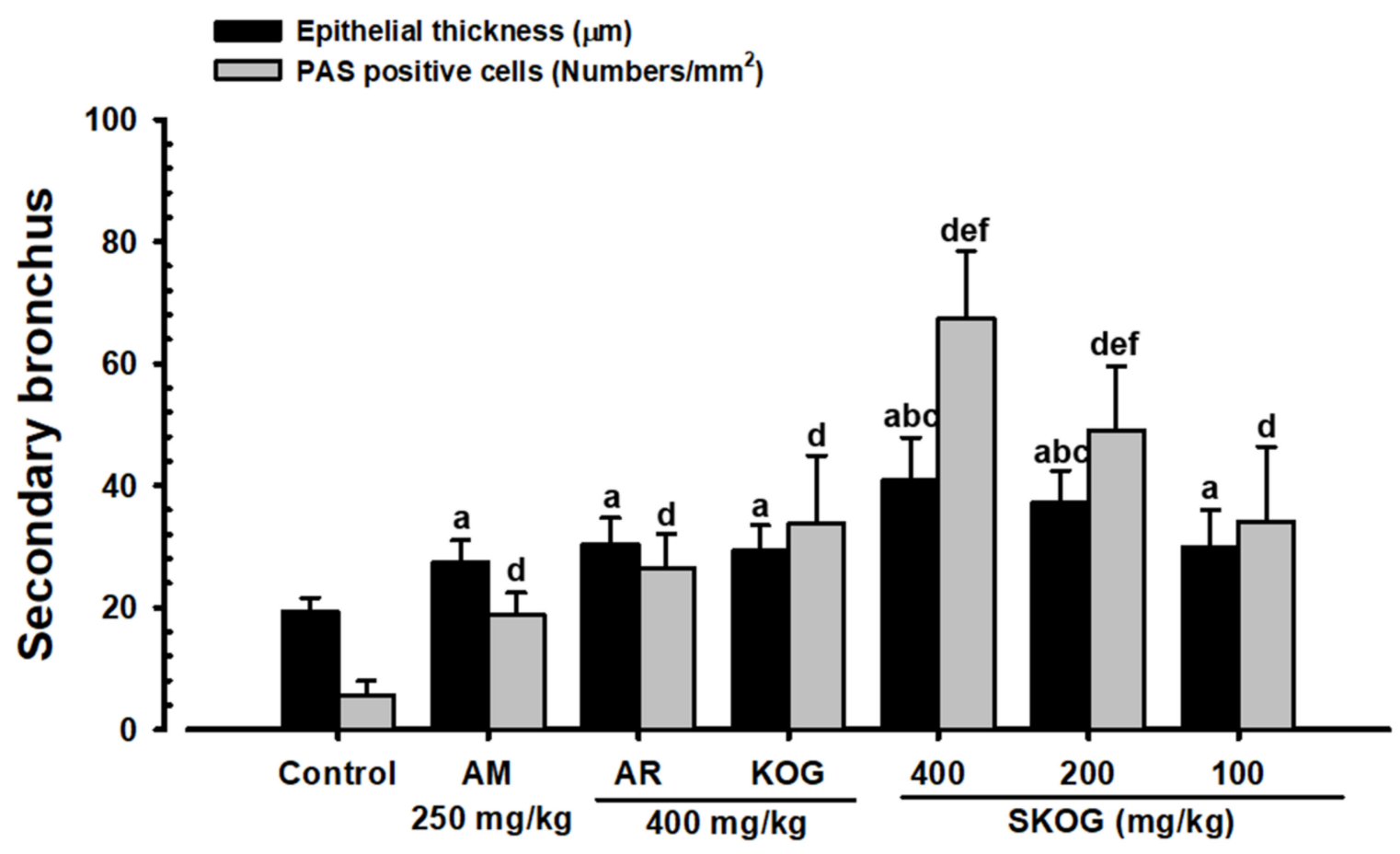

Figure 6. Effects of AR, KOG, and SKOG on the intrapulmonary secondary bronchus epithelial thicknesses and PAS-positive mucous producing cell numbers in mice. Values are presented as the mean \pm SD of 10 mice. Different letters indicate statistical significance. Treatment groups expressed as ${ }^{\mathrm{a}} p<0.01$ and ${ }^{\mathrm{d}} p<0.01,{ }^{\mathrm{b}} p<0.01$ and ${ }^{\mathrm{e}} p<0.01$, and ${ }^{\mathrm{c}} p<0.01$ and ${ }^{\mathrm{f}} p<0.01$ compared with the intact vehicle control, AR $400 \mathrm{mg} / \mathrm{kg}$, and KOG $400 \mathrm{mg} / \mathrm{kg}$ by the LSD and MW tests, respectively.

\subsection{Anti-Inflammatory Assay \\ 3.4.1. Changes in BW and BW Gain}

Following 11 days of oral feeding, mice treated with SKOG 400, 200, $100 \mathrm{mg} / \mathrm{kg}$ as well as AR and KOG 400 did not show any significant changes in BW and BW gain, compared with intact vehicle and xylene controls, respectively. However, the DEXA 1 treated mice showed significant $(p<0.01$ or $p<0.05)$ decreases in BW after 2 days of administration and BW gain during 11 days of the feeding, compared with intact vehicle control and xylene control rodents, respectively (Table A3).

\subsubsection{Ear Gross-Findings}

Ear redness and swelling caused by the topical application of xylene were remarkably inhibited in rodents fed with AR and KOG $400 \mathrm{mg} / \mathrm{kg}$, DEXA $1 \mathrm{mg} / \mathrm{kg}$, and SKOG 400, 200 , and $100 \mathrm{mg} / \mathrm{kg}$ in a dose-dependent manner, respectively, compared with the xylene control mice. Among the treatments, SKOG 400 and $200 \mathrm{mg} / \mathrm{kg}$ exhibited clear decreases in ear redness and edema, compared with those rodents that received AR and KOG doses at $400 \mathrm{mg} / \mathrm{kg}$, respectively. Additionally, SKOG $100 \mathrm{mg} / \mathrm{kg}$ observed similar xylene-induced ear redness and edema gross signs, compared with those of AR and KOG $400 \mathrm{mg} / \mathrm{kg}$, respectively. Moreover, SKOG $400 \mathrm{mg} / \mathrm{kg}$ showed favorable decreases in ear redness and edema gross signs, compared with those of DEXA $1 \mathrm{mg} / \mathrm{kg}$, but AR and KOG $400 \mathrm{mg} / \mathrm{kg}$ as well as SKOG 200 and $100 \mathrm{mg} / \mathrm{kg}$ showed slight inhibitory effects on the xylene-induced ear redness and edema, compared with those of DEXA $1 \mathrm{mg} / \mathrm{kg}$, in the current gross observation (Figure S3).

\subsubsection{Changes in Ear Weight}

A topical application of xylene to rodents resulted in significant increases $(p<0.01)$ in the absolute and relative ear weights which were significantly $(p<0.01)$ and dose- 
dependently decreased in rodents when administering with AR and KOG $400 \mathrm{mg} / \mathrm{kg}$, DEXA $1 \mathrm{mg} / \mathrm{kg}$, and SKOG 400, 200, and $100 \mathrm{mg} / \mathrm{kg}$, respectively, compared with the xylene control mice. Among the treatment groups, SKOG 400 and $200 \mathrm{mg} / \mathrm{kg}$ showed significant $(p<0.01$ or $p<0.05)$ decreases in ear weights, compared with those rodents receiving the doses of AR and KOG $400 \mathrm{mg} / \mathrm{kg}$. Of note, SKOG $400 \mathrm{mg} / \mathrm{kg}$ exhibited more favorable inhibitory activities on xylene-induced increases in absolute and relative ear weights in mice than that of the DEXA $1 \mathrm{mg} / \mathrm{kg}$ treated group (Figure 7).

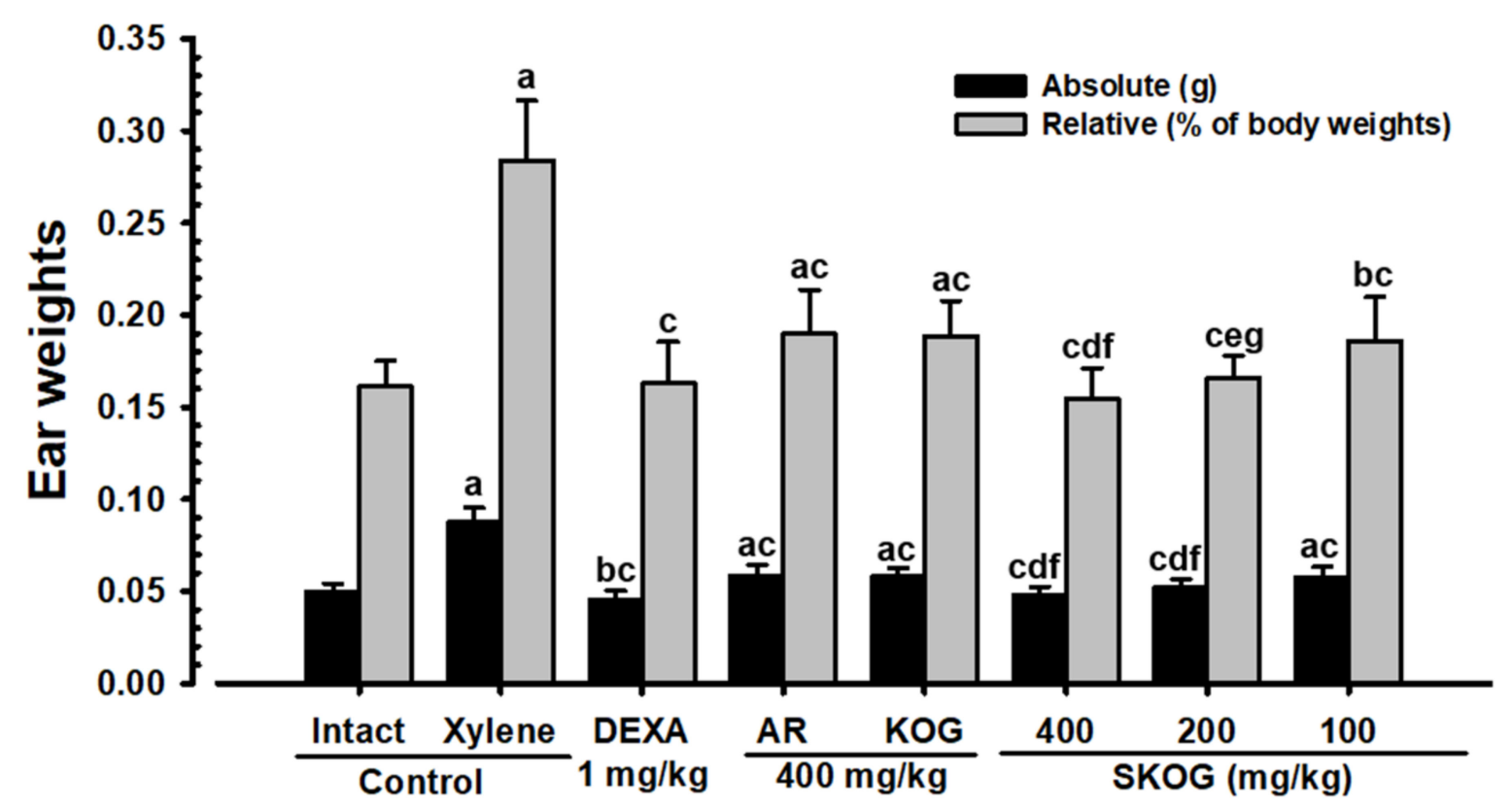

Figure 7. Effects of AR, KOG, and SKOG on the xylene-induced increases of ear weights of mice. Values are presented as the mean \pm SD of 10 mice. Different letters indicate statistical significance. Treatment groups expressed as a $p<0.01$ and ${ }^{\mathrm{b}} p<0.05,{ }^{\mathrm{c}} p<0.01$, and ${ }^{\mathrm{d}} p<0.01$ and ${ }^{\mathrm{e}} p<0.05$, and ${ }^{\mathrm{f}} p<0.01$ and ${ }^{\mathrm{g}} p<0.05$ compared with the intact vehicle control, xylene control, AR $400 \mathrm{mg} / \mathrm{kg}$, and KOG $400 \mathrm{mg} / \mathrm{kg}$ by the LSD test, respectively.

\subsubsection{Histopathological Findings on the Ear}

Significant increases $(p<0.01)$ in the thickness of total ear and ear dermis, number of inflammatory cells on the ear dermis, degranulation-related decreases in the number of mast cells in the dermis, and decreases in collagen fiber-occupied regions in the dermis, as well as no significant changes in the ear epidermis thickness, were observed in the mice with xylene control. However, these xylene-induced ear acute contact dermatitis-related findings, as observed in the histopathological inspection, were significantly inhibited $(p<0.01)$ by SKOG feeding at doses of 400,200 , and $100 \mathrm{mg} / \mathrm{kg}$, compared with those in the xylene control mice. In addition, AR and KOG $400 \mathrm{mg} / \mathrm{kg}$ and DEXA $1 \mathrm{mg} / \mathrm{kg}$ had shown a similar significant inhibition $(p<0.01)$ on xylene-induced ear acute contact dermatitis-related histopathology, compared with xylene control mice. Especially, SKOG 400 and $200 \mathrm{mg} / \mathrm{kg}$ observed significantly increased $(p<0.01)$ inhibitory effects on xylenetreated rodents, compared with those of AR and KOG $400 \mathrm{mg} / \mathrm{kg}$. Additionally, SKOG $400 \mathrm{mg} / \mathrm{kg}$ exerted favorable inhibitory effects on xylene, which were comparable to the effects of DEXA $1 \mathrm{mg} / \mathrm{kg}$. However, AR and KOG $400 \mathrm{mg} / \mathrm{kg}$, SKOG $200 \mathrm{mg} / \mathrm{kg}$, and SKOG $100 \mathrm{mg} / \mathrm{kg}$ showed lower inhibitory effects on xylene than those rodents fed with DEXA $1 \mathrm{mg} / \mathrm{kg}$ (Table 3, Figure 8). 
Table 3. Effects of AR, KOG, and SKOG on the histomorphometry of ear in mice.

\begin{tabular}{|c|c|c|c|c|c|c|}
\hline \multirow{2}{*}{$\begin{array}{l}\text { Index } \\
\text { Groups }\end{array}$} & \multicolumn{3}{|c|}{ Thickness $(\mu \mathrm{m})$} & \multicolumn{2}{|c|}{ Cells (Numbers $/ \mathrm{mm}^{2}$ ) } & \multirow{2}{*}{$\begin{array}{l}\text { Collagen Fiber } \\
\left(\% / \mathrm{mm}^{2} \text { of Dermis }\right)\end{array}$} \\
\hline & Total & Epidermis & Dermis & Inflammatory & Mast & \\
\hline \multicolumn{7}{|l|}{ Controls } \\
\hline Intact & $103.41 \pm 11.47$ & $8.98 \pm 0.93$ & $54.86 \pm 11.97$ & $15.20 \pm 4.66$ & $69.00 \pm 15.48$ & $78.31 \pm 9.75$ \\
\hline Xylene & $264.48 \pm 30.02^{f}$ & $9.07 \pm 1.16$ & $132.28 \pm 22.16^{f}$ & $263.40 \pm 55.50^{f}$ & $8.20 \pm 4.16^{\mathrm{a}}$ & $26.74 \pm 6.58^{f}$ \\
\hline Reference & & & & & & \\
\hline DEXA $1 \mathrm{mg} / \mathrm{kg}$ & $99.55 \pm 9.57^{\mathrm{h}}$ & $8.50 \pm 1.65$ & $52.88 \pm 13.72^{h}$ & $18.10 \pm 10.54^{\mathrm{h}}$ & $61.30 \pm 12.65^{c}$ & $77.43 \pm 12.79^{h}$ \\
\hline $\mathrm{AR} 400 \mathrm{mg} / \mathrm{kg}$ & $166.51 \pm 17.59 \mathrm{fh}$ & $8.77 \pm 0.71$ & $75.41 \pm 8.63^{\mathrm{fh}}$ & $72.30 \pm 14.17^{\mathrm{fh}}$ & $45.20 \pm 10.52^{\mathrm{ac}}$ & $64.73 \pm 10.85^{\mathrm{gh}}$ \\
\hline $\begin{array}{c}\text { KOG } 400 \mathrm{mg} / \mathrm{kg} \\
\text { SKOG }\end{array}$ & $158.83 \pm 13.35^{\mathrm{fh}}$ & $8.76 \pm 0.82$ & $71.55 \pm 5.05^{\mathrm{fh}}$ & $69.00 \pm 12.00^{\mathrm{fh}}$ & $42.40 \pm 6.72^{\mathrm{ac}}$ & $67.59 \pm 4.70 \mathrm{gh}$ \\
\hline $400 \mathrm{mg} / \mathrm{kg}$ & $105.94 \pm 13.74$ hij & $9.15 \pm 1.09$ & $51.58 \pm 6.97$ hij & $29.20 \pm 8.26^{\text {fhij }}$ & $61.00 \pm 10.92$ cde & $81.51 \pm 7.58^{\text {hij }}$ \\
\hline $200 \mathrm{mg} / \mathrm{kg}$ & $128.25 \pm 15.08^{\text {fhij }}$ & $8.28 \pm 1.18$ & $61.37 \pm 6.03^{\mathrm{hij}}$ & $48.40 \pm 14.21^{\text {fhij }}$ & $58.20 \pm 8.53^{\text {bcde }}$ & $76.84 \pm 5.22 \mathrm{hij}$ \\
\hline $100 \mathrm{mg} / \mathrm{kg}$ & $160.57 \pm 18.68^{\mathrm{fh}}$ & $8.73 \pm 0.92$ & $71.69 \pm 10.31^{\mathrm{fh}}$ & $77.70 \pm 21.78^{\mathrm{fh}}$ & $42.80 \pm 10.09^{\mathrm{ac}}$ & $66.43 \pm 10.37 \mathrm{gh}$ \\
\hline
\end{tabular}

Values are expressed as the mean $\pm \mathrm{SD}$ of 10 mice. Different letters indicate statistical significance. Treatment groups expressed as ${ }^{\mathrm{a}} p<0.01$ and ${ }^{\mathrm{b}} p<0.05,{ }^{\mathrm{c}} p<0.01,{ }^{\mathrm{d}} p<0.01$, and ${ }^{\mathrm{e}} p<0.01$ compared with the intact control, xylene control, AR $400 \mathrm{mg} / \mathrm{kg}$, and KOG $400 \mathrm{mg} / \mathrm{kg}$ by the LSD test, respectively. Moreover, treatment groups showed ${ }^{\mathrm{f}} p<0.01$ and $\mathrm{g} p<0.05,{ }^{\mathrm{h}} p<0.01,{ }^{\mathrm{i}} p<0.01,{ }^{\mathrm{j}} p<0.01$ compared with the intact control, xylene control, AR $400 \mathrm{mg} / \mathrm{kg}$, and KOG $400 \mathrm{mg} / \mathrm{kg}$ by the MW test, respectively.

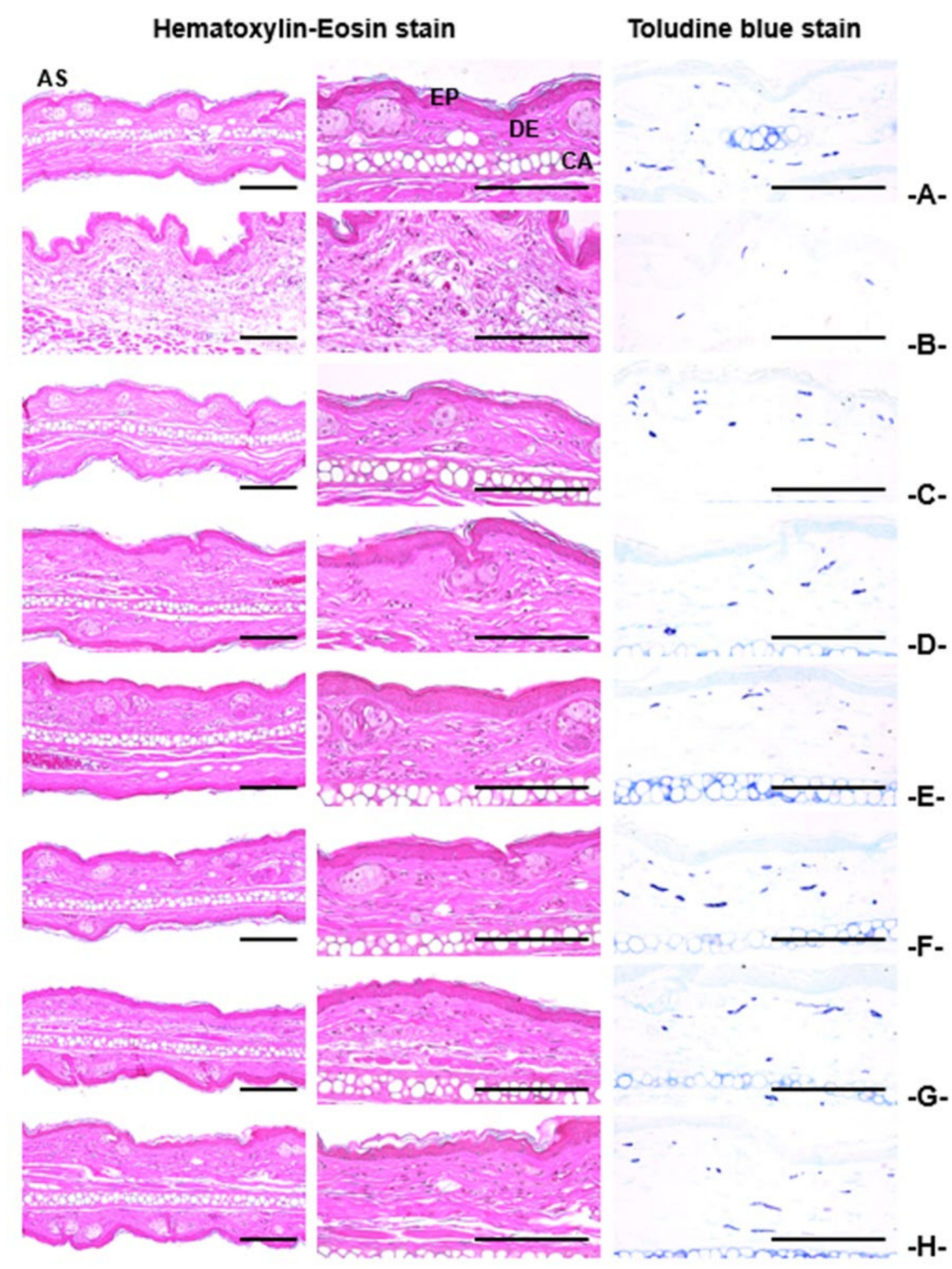

Figure 8. Changes in the histological features of ear in mice. Different treatment groups as followed by the (A) intact vehicle control, (B) xylene control, (C) DEXA $1 \mathrm{mg} / \mathrm{kg}+$ xylene, (D) AR $400 \mathrm{mg} / \mathrm{kg}$ + xylene, (E) KOG $400 \mathrm{mg} / \mathrm{kg}$ + xylene, (F) SKOG $400 \mathrm{mg} / \mathrm{kg}+$ xylene, (G) SKOG $200 \mathrm{mg} / \mathrm{kg}$ + xylene, and (H) SKOG $100 \mathrm{mg} / \mathrm{kg}+$ xylene. Scale bar = $120 \mu \mathrm{m}$. AS: Anterior Surface; CA: Cartilage; DE: Dermis; EP: Epidermis. 


\section{Discussion}

The phytochemical observation on SKOG signified its medicinal value by the presence of various pharmacological important bioactive compounds, which was identified and quantified by the UPLC analysis. SKOG was mainly composed of lupeol, syringaldehyde, $5 \mathrm{H} 2 \mathrm{~F}$, acteoside, catalposide, and $\mathrm{Rg} 3$ compounds, which were a direct or indirect link to the current activities of SKOG. It has been extensively documented that the following identified compounds are believed to be a potential source of bioactivities such as an anti-inflammatory and anti-cancer activities of lupeol [30]; antioxidant and antimicrobial activities of syringaldehyde [31]; antioxidative, anti-hypoxic, anti-allergic, anti-sickling, anti-inflammatory, and anti-hyperuricemic effects of 5H2F [32]; antioxidant and antihypertensive activities of acteoside [33]; preventing mucosal inflammation of catalposide [34]; ameliorating cancer, lung injury, depression, and diabetes of Rg3 [35].

During the 11-day treatment with different test substances, all the mice in three different models such as antitussive, expectorant, and anti-inflammatory assays showed a normal BW and BW gain that fell in the range of age-matched, normal reference mice [36], except for the xylene-induced acute inflammation rodents fed with DEXA $1 \mathrm{mg} / \mathrm{kg}$. In addition, compared with those in the rodents fed with AR and KOG $400 \mathrm{mg} / \mathrm{kg}$, no significant changes in BW and BW gain were shown in the rodents fed with SKOG 400, 200, and $100 \mathrm{mg} / \mathrm{kg}$ in all the three different assays. The xylene-induced acute inflammation mice treated with DEXA $1 \mathrm{mg} / \mathrm{kg}$ showed significant decreases in BW from 2 days after the initial feeding and in BW gain during the treatment period, when compared with the intact vehicle and xylene control animals. A decrease in BW after the treatment with DEXA has been detected as a major side effect of DEXA in other animal studies of anti-inflammatory effects [26,37].

The $\mathrm{NH}_{4} \mathrm{OH}$ has been a well-known antitussive agent to induce the coughing frequency with characteristic acute inflammation in airways $[25,26]$. The mouse model of $\mathrm{NH}_{4} \mathrm{OH}$ exposure-induced coughing was used to confirm whether the antitussive effects of KOG were potentiated by the appropriate addition of AR. ASA is directly related to the gas exchange capacity of the lung; a higher ASA means a higher gas exchange capacity $[26,27,38]$. In the antitussive experiment, the $\mathrm{NH}_{4} \mathrm{OH}$-induced allergic acute inflammation with coughing responses and decreased ASA were dose dependently and significantly inhibited by the feeding of SKOG at doses of 400,200 , and $100 \mathrm{mg} / \mathrm{kg}$. These findings are considered a piece of direct evidence that the appropriate addition of AR to KOG synergistically increased the antitussive activities, at least in the conditions of the current study.

Expectorant agents have the ability to increase the hydration of secretions so that the irritating respiratory tract becomes lubricated [14]. Therefore, the ability to increase the muscus secrtion can be an effective approach to search for a potential drug. Here, the phenol red solution was used to identify whether the expectorant effects of KOG in mice were synergistically potentiated by the appropriate addition of AR. Later, the PAS staining method was performed to evaluate the mucous intensity and number of mucous-producing cells $[28,39,40]$. The result of the study was found to be effective in the effects of SKOG, which showed a significant and dose-dependent expectorant ability in oral administered mice, through enhanced mucous secretion and promoted functional activities of trachea and bronchus mucosa [21-23]. These findings are considered obvious evidence that the appropriate addition of AR synergistically increased the expectorant activities of KOG.

An investigatoin on the anti-inflammatory efficacy of the test substances can easily be achieved following the application of xylene on the anterior surface of the mouse ear to induce acute inflammation in the mouse ear model [14]. In the present study, KOG was investigated by whether the appropriate addition of AR could subsequently promote antiinflammatory potentials, in addition to antitussive and expectorant activities. The xylene control mice are reported to have noticeable changes in the gross sign and weight of the ear with characteristic inflammatory-related histopathological features [25,26]. Following the administration, SKOG at doses of 400 and $200 \mathrm{mg} / \mathrm{kg}$ significantly increased the anti- 
inflammatory effects, compared to those in the mice administered with AR and KOG $400 \mathrm{mg} / \mathrm{kg}$ on xylene-induced acute inflammation in the rodent ear. In addition, SKOG $400 \mathrm{mg} / \mathrm{kg}$ showed anti-inflammatory effects comparable to those of DEXA $1 \mathrm{mg} / \mathrm{kg}$ on xylene-induced acute inflammation in the rodent ear. These findings are considered direct and clear evidence that the appropriate addition of AR synergistically increased the anti-inflammatory activities of KOG, at least in the conditions of the current study. However, further research is warranted as to whether SKOG has some other effective bioactive compound(s) and whether their molecular mechanism of actions is responsible for the synergistic effects in the current study. Similarly, changes in the relative lung weight could have been measured to ensure that there are no significant changes due to the treatments and that also needs to be addressed in further studies.

\section{Conclusions}

In conclusion, our study suggested that the appropriate addition of AR to KOG in order to prepare the SKOG recipe exhibited significant and synergistic effects in antitussive, expectorant, and anti-inflammatory activities by potentiating the modulation of the activities of respiratory mucous-producing cells and mast cells in animal models. The most effective doses of SKOG were found to be 400 and $200 \mathrm{mg} / \mathrm{kg}$, compared to those in the mice fed with AR and KOG $400 \mathrm{mg} / \mathrm{kg}$, suggesting that an effective portion of bioactive compounds is present at these doses. These findings were considered as pharmacological shreds of evidence for the traditional use of AR and KOG as antitussive, expectorant, and anti-inflammatory remedies. Therefore, it is expected that SKOG may serve as a preventive or therapeutic agent in varied respiratory diseases, particularly those caused by environmental toxicants.

Supplementary Materials: The following are available online at https:/ /www.mdpi.com/2076-341 7/11/3/1349/s1, Figure S1: UPLC analysis of identification and quantification of lupeol, syringaldehyde, 5H2F, acteoside, catalposide, and Rg3 ingredients in SKOG, a mixture of AR and KOG. (A) standard for AR, (B) Test AR, (C) standard for KOG, (D) Test KOG, (E) standard for SKOG, and (F) Test SKOG., Table S1: Composition of KOG and SKOG used in this study.

Author Contributions: Conceptualization, S.-K.K. and J.-S.C.; methodology, J.-R.H. and S.-K.K.; validation, D.-H.J., M.M., and S.-K.K.; formal analysis, S.-M.K., S.-K.K. and H.-J.L.; investigation, S.-M.K., D.-H.J. and S.-K.K.; resources, C.-J.J. and S.-K.K.; data curation, S.-K.K. and D.-H.J.; writing-original draft preparation, S.-K.K. and H.-J.L.; writing-review and editing, M.M. and J.-S.C.; visualization, J.-R.H. and S.-K.K.; supervision, S.-K.K., H.-J.L., and J.-S.C.; project administration, D.-H.J. and S.-K.K.; funding acquisition, S.-K.K. All authors have read and agreed to the published version of the manuscript.

Funding: This work was supported by the National Research Foundation of Korea grant, funded by the Korea government (MSIT) (no. 2018R1A5A2025272).

Institutional Review Board Statement: Antitussive, expectorant and anti-inflammatory experiments in this study were approved by the Institutional Animal Care and Use Committee of Daegu Haany University. The approval numbers were DHU2016-034, DHU2016-035 and DHU2016-036, respectively.

Data Availability Statement: Data supporting reported results can be made available on demand.

Conflicts of Interest: The authors declare no conflict of interest. 


\section{Appendix A}

Table A1. Changes on the body weight gains in antitussive assay.

\begin{tabular}{|c|c|c|c|}
\hline \multirow{2}{*}{$\begin{array}{ll}\text { Groups } & \text { Periods } \\
\end{array}$} & \multicolumn{2}{|c|}{ Body Weights (g) at Test Material Administration } & \multirow{2}{*}{$\begin{array}{l}\text { Body Weight Gains (g) } \\
\text { [B - A ] }\end{array}$} \\
\hline & First $[\mathrm{A}]$ & Last [B] & \\
\hline \multicolumn{4}{|l|}{ Controls } \\
\hline Intact & $29.34 \pm 1.29$ & $30.98 \pm 1.39$ & $1.64 \pm 0.74$ \\
\hline $\mathrm{NH}_{4} \mathrm{OH}$ & $29.44 \pm 1.65$ & $31.11 \pm 2.22$ & $1.67 \pm 0.84$ \\
\hline \multicolumn{4}{|l|}{ Reference } \\
\hline TB $50 \mathrm{mg} / \mathrm{kg}$ & $29.23 \pm 1.49$ & $30.94 \pm 1.77$ & $1.71 \pm 0.97$ \\
\hline $\mathrm{AR} 400 \mathrm{mg} / \mathrm{kg}$ & $29.41 \pm 0.96$ & $31.12 \pm 1.74$ & $1.71 \pm 1.18$ \\
\hline KOG $400 \mathrm{mg} / \mathrm{kg}$ & $29.58 \pm 1.24$ & $31.10 \pm 1.56$ & $1.52 \pm 0.61$ \\
\hline \multicolumn{4}{|l|}{ SKOG } \\
\hline $400 \mathrm{mg} / \mathrm{kg}$ & $29.66 \pm 1.07$ & $31.35 \pm 1.34$ & $1.69 \pm 0.70$ \\
\hline $200 \mathrm{mg} / \mathrm{kg}$ & $29.27 \pm 0.75$ & $31.04 \pm 0.62$ & $1.77 \pm 0.32$ \\
\hline $100 \mathrm{mg} / \mathrm{kg}$ & $29.41 \pm 0.86$ & $30.92 \pm 1.17$ & $1.51 \pm 0.88$ \\
\hline
\end{tabular}

Values are expressed mean $\pm \mathrm{SD}$ of 10 mice, $\mathrm{NH}_{4} \mathrm{OH}=$ Ammonia hydroxide, $\mathrm{TB}=$ Theobromine, $\mathrm{AR}=$ Adenophorae Radix (dried root parts of Adenophora triphylla var. japonica Hara) powders, KOG = Kyeongok-go, Traditional mixed herbal formulation, SKOG = ShashamKyeongok-go, KOG contains AR powders, Test material.

Table A2. Changes on the body weight gains in expectorant assay.

\begin{tabular}{|c|c|c|c|}
\hline \multirow{2}{*}{ Groups $\quad$ Periods } & \multicolumn{2}{|c|}{ Body Weights (g) at Test Material Administration } & \multirow{2}{*}{$\begin{array}{c}\text { Body Weight Gains (g) } \\
{[\mathrm{B}-\mathrm{A}]}\end{array}$} \\
\hline & First $[A]$ & Last [B] & \\
\hline \multicolumn{4}{|l|}{ Controls } \\
\hline Intact & $29.09 \pm 1.23$ & $30.96 \pm 1.01$ & $1.87 \pm 0.60$ \\
\hline \multicolumn{4}{|l|}{ Reference } \\
\hline $\mathrm{AM} 250 \mathrm{mg} / \mathrm{kg}$ & $29.23 \pm 1.16$ & $31.22 \pm 1.65$ & $1.99 \pm 0.73$ \\
\hline AR $400 \mathrm{mg} / \mathrm{kg}$ & $29.40 \pm 0.81$ & $31.11 \pm 1.25$ & $1.71 \pm 0.85$ \\
\hline $\mathrm{KOG} 400 \mathrm{mg} / \mathrm{kg}$ & $29.00 \pm 1.60$ & $30.69 \pm 1.77$ & $1.69 \pm 0.90$ \\
\hline \multicolumn{4}{|l|}{ SKOG } \\
\hline $400 \mathrm{mg} / \mathrm{kg}$ & $29.26 \pm 1.12$ & $31.01 \pm 1.76$ & $1.75 \pm 1.02$ \\
\hline $200 \mathrm{mg} / \mathrm{kg}$ & $29.20 \pm 1.26$ & $31.25 \pm 1.83$ & $2.05 \pm 0.92$ \\
\hline $100 \mathrm{mg} / \mathrm{kg}$ & $29.18 \pm 1.04$ & $31.23 \pm 1.76$ & $2.05 \pm 1.03$ \\
\hline
\end{tabular}

Values are expressed mean $\pm \mathrm{SD}$ of 10 mice, $\mathrm{AM}=\mathrm{Ambroxol}, \mathrm{AR}=$ Adenophorae Radix (dried root parts of Adenophora triphylla var. japonica Hara) powders, KOG = Kyeongok-go, Traditional mixed herbal formulation, SKOG = ShashamKyeongok-go, KOG contains AR powders, Test material.

Table A3. Changes on the body weight gains in anti-inflammatory assay.

\begin{tabular}{|c|c|c|c|}
\hline \multirow[t]{2}{*}{ Periods } & \multicolumn{2}{|c|}{ Body Weights (g) at Test Material Administration } & \multirow{2}{*}{$\begin{array}{c}\text { Body Weight Gains (g) } \\
{[B-A]}\end{array}$} \\
\hline & First $[A]$ & Last [B] & \\
\hline \multicolumn{4}{|l|}{ Controls } \\
\hline Intact & $28.94 \pm 1.06$ & $31.04 \pm 1.49$ & $2.10 \pm 0.90$ \\
\hline Xylene & $28.93 \pm 1.01$ & $30.97 \pm 1.62$ & $2.04 \pm 0.79$ \\
\hline \multicolumn{4}{|l|}{ Reference } \\
\hline DEXA $1 \mathrm{mg} / \mathrm{kg}$ & $28.72 \pm 1.10$ & $27.80 \pm 1.66^{\mathrm{ab}}$ & $-0.92 \pm 0.76^{\mathrm{ab}}$ \\
\hline AR $400 \mathrm{mg} / \mathrm{kg}$ & $28.99 \pm 1.21$ & $31.12 \pm 2.51$ & $2.13 \pm 1.63$ \\
\hline KOG $400 \mathrm{mg} / \mathrm{kg}$ & $29.20 \pm 1.11$ & $31.02 \pm 1.78$ & $1.82 \pm 1.01$ \\
\hline \multicolumn{4}{|l|}{ SKOG } \\
\hline $400 \mathrm{mg} / \mathrm{kg}$ & $29.11 \pm 1.27$ & $31.29 \pm 2.19$ & $2.18 \pm 1.34$ \\
\hline $200 \mathrm{mg} / \mathrm{kg}$ & $28.95 \pm 1.26$ & $31.29 \pm 1.66$ & $2.34 \pm 0.70$ \\
\hline $100 \mathrm{mg} / \mathrm{kg}$ & $29.07 \pm 0.72$ & $31.08 \pm 1.10$ & $2.01 \pm 0.86$ \\
\hline
\end{tabular}

Values are expressed mean $\pm \mathrm{SD}$ of 10 mice, $\mathrm{AR}=$ Adenophorae Radix (dried root parts of Adenophora triphylla var. japonica Hara) powders, KOG = Kyeongok-go, Traditional mixed herbal formulation, SKOG = ShashamKyeongok-go, KOG contains AR powders, Test material. $\mathrm{DEXA}=$ Dexamethasone, ${ }^{\mathrm{a}} p<0.01$ as compared with intact control by LSD test, ${ }^{\mathrm{b}} p<0.01$ as compared with xylene control by LSD test. 


\section{References}

1. Pavord, I.D. Cough and asthma. Pulm. Pharmacol. Ther. 2004, 17, 399-402. [CrossRef] [PubMed]

2. Dapaah, G.; Koffuor, G.A.; Mante, P.K.; Ben, I.O. Antitussive, expectorant and analgesic effects of the ethanol seed extract of Picralima nitida (Stapf) Th. \& H. Durand. Res. Pharm. Sci. 2016, 11, 100. [PubMed]

3. GBD 2016 Disease and Injury Incidence and Prevalence Collaborators. Global, regional, and national incidence, prevalence, and years lived with disability for 328 diseases and injuries for 195 countries, 1990-2016: A systematic analysis for the Global Burden of Disease Study 2016. Lancet 2017, 390, 1211-1259. [CrossRef]

4. Sanak, M. Eicosanoid mediators in the airway inflammation of asthmatic patients: What is new? Allergy Asthma Immunol. Res. 2016, 8, 481-490. [CrossRef] [PubMed]

5. Woloski, J.R.; Heston, S.; Calderon, S.P.E. Respiratory Allergic Disorders. Prim. Care Clin. Off. Pract. 2016, 43, 401-415. [CrossRef] [PubMed]

6. Konno, C.; Saito, T.; Oshima, Y.; Hikino, H.; Kabuto, C. Structure of methyl adenophorate and triphyllol, triterpenoids of Adenophora triphylla var. japonica roots. Planta Med. 1981, 42, 268-274. [CrossRef]

7. Kim, J.B.; Song, H.N. Effects of Kyeongok-go and its two added precriptions on hyperlipidemic rats induced by high-fat diet. J. Physiol. Pathol. Korean Med. 2014, 28, 371-378. [CrossRef]

8. Lee, D.-R.; Lee, Y.-S.; Choi, B.-K.; Lee, H.J.; Park, S.-B.; Kim, T.-M.; Oh, H.J.; Yang, S.H.; Suh, J.-W. Roots extracts of Adenophora triphylla var. japonica improve obesity in 3T3-L1 adipocytes and high-fat diet-induced obese mice. Asian Pac. J. Trop. Med. 2015, 8, 898-906. [CrossRef]

9. Asano, N.; Nishida, M.; Miyauchi, M.; Ikeda, K.; Yamamoto, M.; Kizu, H.; Kameda, Y.; Watson, A.A.; Nash, R.J.; Fleet, G.W.J. Polyhydroxylated pyrrolidine and piperidine alkaloids from Adenophora triphylla var. japonica (Campanulaceae). Phytochemistry 2000, 53, 379-382. [CrossRef]

10. Ahn, E.K.; Oh, J.S. Lupenone isolated from Adenophora triphylla var. japonica extract inhibits adipogenic differentiation through the downregulation of PPAR $\gamma$ in 3T3-L1 cells. Phytother. Res. 2013, 27, 761-766. [CrossRef]

11. Yoon, Y.P.; Lee, H.J.; Lee, D.-U.; Lee, S.K.; Hong, J.-H.; Lee, C.J. Effects of lupenone, lupeol, and taraxerol derived from Adenophora triphylla on the gene expression and production of airway MUC5AC mucin. Tuberc. Respir. Dis. 2015, 78, 210-217. [CrossRef] [PubMed]

12. Kang, M.; Ha, I.J.; Chun, J.; Kang, S.S.; Kim, Y.S. Separation of two cytotoxic saponins from the roots of Adenophora triphylla var. japonica by High-speed Counter-current Chromatography. Phytochem. Anal. 2013, 24, 148-154. [CrossRef]

13. Chun, J.; Kang, M.; Kim, Y.S. A triterpenoid saponin from Adenophora triphylla var. japonica suppresses the growth of human gastric cancer cells via regulation of apoptosis and autophagy. Tumor Biol. 2014, 35, 12021-12030. [CrossRef] [PubMed]

14. Hu, J.R.; Jung, C.J.; Ku, S.M.; Jung, D.H.; Ku, S.K.; Choi, J.S. Antitussive, expectorant, and anti-inflammatory effects of Adenophorae Radix powder in ICR mice. J. Ethnopharmacol. 2019, 239, 111915. [CrossRef] [PubMed]

15. Na, C.-S.; Shin, W.; Lee, Y.-M.; Moon, Y.-S.; Noh, H.-k.; Seo, S.-H.; Son, H.-S. Effect of original kyungokgo \& iksuyongjingo plus Sparassis crispa on antioxidant, immunity improvement and sensory evaluation. Korea J. Herbol. 2016, 31, 43-51.

16. Lee, K.-S.; Kim, G.-H.; Kim, H.-H.; Seong, B.-J.; Kim, S.-I.; Han, S.-H.; Kang, E.J.; Yoo, Y.C. Qualities and anti-inflammatory activity of Kyungokgos sold in local markets. J. Korean Soc. Food Sci. Nutr. 2013, 42, 335-341. [CrossRef]

17. Kim, J.-H.; Lee, J.-H.; Oh, J.-M.; Kim, Y.-K. Inhibitory effects on bone resorption and osteoblast proliferation of Kyungok-go. Herb. Formula Sci. 2011, 19, 61-71.

18. Cha, Y.-Y. A Comparative Study on Effects of Kyungohkgo and Kyungohkgo Ga Nokyong on growth in growth deficiency rat with insufficient nutrition diet. J. Korean Med. Obes. Res. 2009, 9, 59-69.

19. Zhang, J.-L.; Wang, H.; Pi, H.-F.; Ruan, H.-L.; Zhang, P.; Wu, J.-Z. Structural analysis and antitussive evaluation of five novel esters of verticinone and bile acids. Steroids 2009, 74, 424-434. [CrossRef]

20. Wanga, D.; Wanga, S.; Chena, X.; Xua, X.; Zhub, J.; Nieb, L.; Longa, X. Antitussive, expectorant and anti-inflammatory activities of four alkaloids isolated from Bulbus of Fritillaria wabuensis. J. Ethnopharmacol. 2012, 139, 189-193. [CrossRef]

21. Engler, H.; Szelenyi, I. Tracheal phenol red secretion, a new method for screening mucosecretolytic compounds. J. Pharmacol. Methods 1984, 11, 151-157. [CrossRef]

22. Cho, K.-H.; Kim, H.-D.; Lee, B.-W.; Lim, M.-K.; Ku, S.K. Effects of magnetic infrared laser on xylene-induced acute inflammation in mice. J. Phys. Ther. Sci. 2008, 20, 255-259. [CrossRef]

23. Lee, H.-S.; Ku, S.-K. Effects of Picrorrhiza Rhizoma on acute inflammation in mice. Biomol. Ther. 2008, 16, 137-140. [CrossRef]

24. Ministry of Food and Drug Safety. The Korean Pharmacopoeia (The Korea Food and Drug Administration Notification 2012-9); Ministry of Food and Drug Safety: Cheongju, Korea, 2012.

25. Lebargy, F.; Lenormand, E.; Pariente, R.; Fournier, M. Morphological changes in rat tracheal mucosa immediately after antigen challenge. Bull. Eur. Physiopathol. Respir. 1987, 23, 417-421. [PubMed]

26. Ku, S.K.; Kim, J.W.; Cho, H.R.; Kim, K.Y.; Min, Y.H.; Park, J.H.; Kim, J.S.; Park, J.H.; Seo, B.I.; Roh, S.S. Effect of $\beta$-glucan originated from Aureobasidium pullulans on asthma induced by ovalbumin in mouse. Arch. Pharmacal Res. 2012, 35, 1073-1081. [CrossRef]

27. Choi, H.-Y.; Jung, T.-Y.; Ku, S.-K.; Yang, H.-B.; Lee, H.-S. Toxico-pathological study p, p-DDE after experimental aerosol exposed to ICR mouse. Toxicol. Res. 2005, 21, 151-160. 
28. Honda, H.; Fujimoto, M.; Miyamoto, S.; Ishikawa, N.; Serada, S.; Hattori, N.; Nomura, S.; Kohno, N.; Yokoyama, A.; Naka, T. Sputum leucine-rich alpha-2 glycoprotein as a marker of airway inflammation in asthma. PLoS ONE 2016, 11, e0162672. [CrossRef]

29. Lee, C.W.; Park, S.M.; Kim, Y.S.; Jegal, K.H.; Lee, J.R.; Cho, I.J.; Ku, S.K.; Lee, J.Y.; Ahn, Y.-T.; Son, Y. Biomolecular evidence of anti-inflammatory effects by Clematis mandshurica Ruprecht root extract in rodent cells. J. Ethnopharmacol. 2014, 155, 1141-1155. [CrossRef]

30. Saleem, M. Lupeol, a novel anti-inflammatory and anti-cancer dietary triterpene. Cancer Lett. 2009, 285, 109-115. [CrossRef]

31. Ibrahim, M.N.M.; Balakrishnan, R.B.S.; Shamsudeen, S.; Bahwani, S.A.; Adam, F. A concise review of the natural existance, synthesis, properties, and applications of syringaldehyde. Bioresources 2012, 7, 4377-4399.

32. Shapla, U.M.; Solayman, M.; Alam, N.; Khalil, M.I.; Gan, S.H. 5-Hydroxymethyl furfural (HMF) levels in honey and other food products: Effects on bees and human health. Chem. Cent. J. 2018, 12, 35. [CrossRef] [PubMed]

33. Chao-Hsiang, C.; Yin-Shiou, L.I.N.; Chien, M.-Y.; Wen-Chi, H.O.U.; Miao-Lin, H.U. Antioxidant and antihypertensive activities of acteoside and its analogs. Bot. Stud. 2012, 53, 421-429.

34. Kim, S.-W.; Choi, S.-C.; Choi, E.-Y.; Kim, K.-S.; Oh, J.-M.; Lee, H.-J.; Oh, H.-M.; Kim, S.; Oh, B.-S.; Kimm, K.-C. Catalposide, a compound isolated from Catalpa ovata, attenuates induction of intestinal epithelial proinflammatory gene expression and reduces the severity of trinitrobenzene sulfonic acid-induced colitis in mice. Inflamm. Bowel Dis. 2004, 10, 564-572. [CrossRef] [PubMed]

35. Zhang, H.; Zhou, Z.; Chen, Z.; Zhong, Z.; Li, Z. Ginsenoside Rg3 exerts anti-depressive effect on an NMDA-treated cell model and a chronic mild stress animal model. J. Pharmacol. Sci. 2017, 134, 45-54. [CrossRef] [PubMed]

36. Horiuchi, S.; Koshimizu, K. Biological Reference Data Book on Experimental Animals; Soft Science: Tokyo, Japan, $1989 ;$ p. 158.

37. Kim, H.-D.; Cho, K.-H.; Lee, B.-W.; Kwon, Y.-S.; Lee, H.-S.; Choi, S.-H.; Ku, S.-K. Effects of magnetic infrared laser irradiation on formalin-induced chronic paw inflammation of mice. J. Phys. Ther. Sci. 2010, 22, 395-404. [CrossRef]

38. Davey, M.G.; Hedrick, H.L.; Mendoza, J.M.; Kanai, M.; Adzick, N.S.; Flake, A.W. Pulmonary epithelial liquid absorption, expressed in relation to alveolar surface area, is reduced in fetal lambs following in utero tracheal occlusion. Pediatric Pulmonol. 2002, 34, 278-286. [CrossRef] [PubMed]

39. Tam, A.; Wadsworth, S.; Dorscheid, D.; Man, S.-F.P.; Sin, D.D. Estradiol increases. mucus synthesis in bronchial epithelial cells. PLoS ONE 2014, 9, e100633. [CrossRef] [PubMed]

40. Kim, C.G.; Kang, M.; Lee, Y.-H.; Min, W.G.; Kim, Y.H.; Kang, S.J.; Song, C.H.; Park, S.J.; Park, J.H.; Han, C.H. Bathing effects of various seawaters on allergic (atopic) dermatitis-like skin lesions induced by 2, 4-dinitrochlorobenzene in hairless mice. Evid.-Based Complement. Altern. Med. 2015, 2015, 179185. [CrossRef] 